Brigham Young University Law School

BYU Law Digital Commons

Faculty Scholarship

$1-1-2016$

Plenary Power, Political Questions, and Sovereignty in Indian Affairs

Michalyn Steele

BYU Law, steelem@law.byu.edu

Follow this and additional works at: https://digitalcommons.law.byu.edu/faculty_scholarship

Part of the Indian and Aboriginal Law Commons

Recommended Citation

Michalyn Steele, Plenary Power, Political Questions, and Sovereignty in Indian Affairs, 63 UCLA L. Rev. 666 (2016).

This Article is brought to you for free and open access by BYU Law Digital Commons. It has been accepted for inclusion in Faculty Scholarship by an authorized administrator of BYU Law Digital Commons. For more information, please contact hunterlawlibrary@byu.edu. 


\title{
Plenary Power, Political Questions, and Sovereignty in Indian Affairs
}

\author{
Michalyn Steele
}

\begin{abstract}
A generation of Indian law scholars has roundly, and rightly, criticized the Supreme Court's invocation of the political question and plenary power doctrines to deprive tribes of meaningful judicial review when Congress has acted to the tribes' detriment. Courts have applied these doctrines in tandem so as to frequently leave tribes without meaningful judicial recourse against breaches of the federal trust responsibility or intrusions upon tribal interests and sovereignty. For example, courts consider congressional abrogation of a treaty a political question beyond the reach of the judiciary. At the same time, challenges to the inherent, or aboriginal, authority of tribes are deemed justiciable. The Court's inconsistent approach represents a kind of "heads I win; tails you lose" application of the political question and plenary power doctrines in Indian affairs.

This Article proposes that, rather than facing a rigged coin toss in the courts, tribes should be able to avail themselves of the political question and plenary power doctrines to have Congress, rather than the courts, decide questions of inherent tribal authority. Under current precedent, the Court has aggrandized its own power in Indian affairs through the theory of implicit divestiture, which holds that the judiciary may find tribes divested of inherent powers even without congressional action. This Article argues that the questions of whether inherent tribal authority endures, and which sovereign powers tribes can exercise, should be political rather than judicial. This Article challenges longheld assumptions about these fundamental doctrines of federal Indian law and poses important questions about the role of the courts and Congress and about the future of inherent tribal sovereignty.
\end{abstract}

\section{AUTHOR}

Associate Professor, Brigham Young University Law. I thank Matthew L.M. Fletcher, Alex Tallchief Skibine, and Rebecca Tsosie for their encouragement, and my colleagues at BYU Law for their insightful comments. Special thanks to Brigham Daniels, RonNell Andersen Jones, David Moore, Felicity Murphy, Paul Stancil, and Lisa Grow Sun.

63 UCLA L. Rev. 666 (2016) 


\section{TABLE OF CONTENTS}

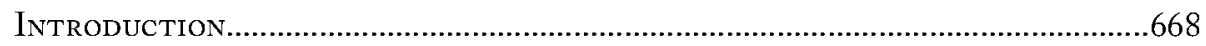

I. Sovereignty and the Inherent Power of Tribes ......................................674

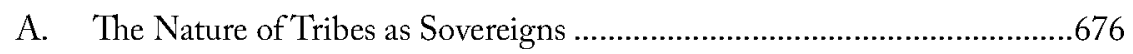

B. The Inherent Tribal Sovereignty Doctrine ..............................................678

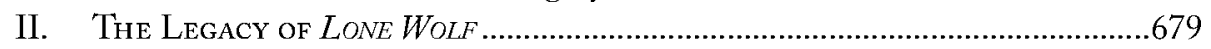

A. The Plenary Power Doctrine …................................................................68

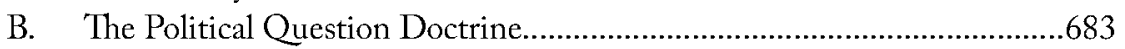

III. Implicit Divestiture and the Inherent Tribal Sovereignty

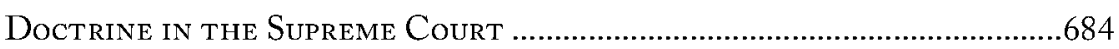

IV. Inherent Tribal Authority as a Political Question...............................687

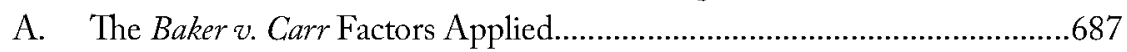

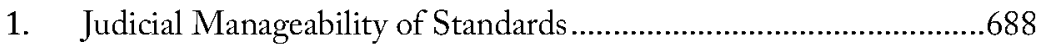

a. External Relations and Internal Power ..................................690

b. Neccessary to Protect Self-Government...................................694

c. Inconsistent with Dependent Status......................................697

2. Textual Commitment to Coordinate Branch.................................699

3. Initial Policy Determinations of a Kind Clearly

for Non-Judicial Discretion ............................................................702

B. The Effects and Limits of the Political Question Doctrine ........................706

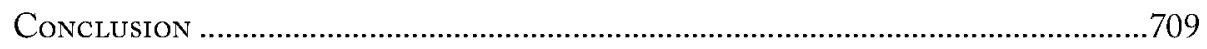




\section{INTRODUCTION}

The Haudenosaunee, commonly referred to as the confederated Iroquois Nations, use stringed beads woven into belts to solemnize agreements and formalize diplomatic relations. ${ }^{1}$ In the early seventeenth century, for example, the Iroquois used what is known as the Gus-wen-tah, or Two Row Wampum, to memorialize the relationship of mutual trust and respect between the Iroquois Nations and the Dutch. It consists of precious shells woven together to create two parallel purple lines that sit against a white background. The Two Row Wampum's parallel lines represent the paths of two canoes traveling side by side down a river. ${ }^{2}$ It embodies the Haudenosaunee ideal of the parallel sovereignty of the tribes in their relations with other nations. They travel together and neither undertakes to "steer the other's vessel."

Unfortunately, this ideal of the peacefully coexisting sovereigns traveling parallel, mutually beneficial paths has rarely, if ever, been realized in relations between tribes and the United States. Instead, not only has the United States frequently sought to steer the canoe of Indian tribal sovereignty, but also, at particularly low points in this journey, the United States pursued policies designed to topple Indian tribes' canoes altogether. ${ }^{4}$ The federal policies of forced

1. WILLIAM N. FENTON, THE GREAT LAW AND THE LONGHOUSE: A POLITICAL HISTORY OF THE IROQUOIS CONFEDERACY 224 (1998). The tribal nations of the Iroquois Confederacy, or Haudenosaunee (sometimes spelled "Ho-de-no-sau-nee") as they called themselves, are the Seneca, Cayuga, Onondaga, Oneida, and Mohawk. RICHARD AQULLA, THE IROQUOIS RESTORATION: IROQUOIS DIPLOMACY ON THE COLONIAL FRONTIER, 1701-1754 at 30 (1983).

2. See Robert B. Porter, A Proposal to the Hanodaganyas to Decolonize Federal Indian Control Law, 31 U.MICH.J.L. REFORM 899, 987-88 (1998) ("There is a bed of white wampum which symbolizes the purity of the agreement. There are two rows of purple, and those two rows have the spirit of your ancestors and mine. There are three beads of wampum separating the two rows and they symbolize peace, friendship, and respect." (quoting SPECIAL COMMITTEE ON INDIAN SELFGOVERNMENT, INDIAN SELF-GOVERNMENT IN CANADA back cover (1983))); of. Desmond Manderson, The Law of the Image and the Image of the Law: Colonial Representations of the Rule of Law, 57 N.Y.L. SCH. L. REV. 153, 166 (2012-2013) (observing that the Two Row Wampum "recognizes ... communities whose difference is valuable to them and worthy of respect, and whose trajectories may therefore not be identical."). For an example of the Two-Row Wampum, see Appendix A: The Two-Row Wampum.

3. Robert B. Porter, Legalizing, Decolonizing, and Modernizing New York State's Indian Law, 63 ALB. L. REV. 125, 182 (1999) ("The Two Row Wampum requires that We shall each travel the river together, side by side, but in our own boat. Neither of us will try to steer the other's vessel.").

4. See, e.g., General Allotment Act, ch. 119, 24 Stat. 388 (repealed 2000); County of Yakima v. Confederated Tribes \& Bands of the Yakima Indian Nation, 502 U.S. 251, 254 (1992) (discussing the period of the assimilation and commenting that Congress intended "to extinguish tribal 
assimilation, allotment, and termination were each designed to end tribal political and cultural identity. ${ }^{5}$ Tribal nations continue to face rough political and socioeconomic waters in the forms of pronounced poverty, educational deficits, and health disparities. ${ }^{6}$

Despite the United States' history of ill-considered and destructive Indian policies, the ideal of tribal self-governance and sovereignty still endures. And to be sure, tribal self-determination and self-governance are stated policies of the United States. ${ }^{7}$ But in recent decades, enhanced tribal self-determination as articulated by the political branches has faced its greatest impediment: the Supreme Court of the United States. ${ }^{8}$

The political question doctrine in federal Indian law, that courts will not generally second-guess congressional exercise of the Indian affairs power, in concert with a robust congressional plenary power doctrine, has left tribes without meaningful judicial recourse in defending their own interests and sovereignty. ${ }^{9}$ The Supreme Court has long invoked the political question doctrine in varying degrees when tribes have sought judicial review of congressional action. Courts have been reluctant to review congressional action challenged by tribes because of the breadth of congressional power over Indian affairs. This application of the political question doctrine in federal Indian law has been roundly, and rightly,

sovereignty, erase reservation boundaries, and force the assimilation of Indians into the society at large.").

5. Termination policies came in several forms, including policies that revoked recognition of some tribes and extended the reach of other governments (particularly states) onto tribal lands. See generally FELIX S. COHEN, HANDBOOK OF INDLAN LAW 152-80 (1982).

6. See, e.g., EXEc. OfFice ofthe PRESIDENT, 2014 NATIVE YOUTH REPORT 5-6, 14-19 (2014).

7. See, e.g., President Richard Nixon, Special Message to Congress on Indian Affairs (July 8, 1970) (declaring the federal policy of the United States to be self-determination for Indian tribes).

8. See, e.g., Philip S. Deloria \& Nell Jessup Newton, The Criminal Jurisdiction of Tribal Courts Over Non-Member Indians: An Examination of the Basic Framework of Inberent Tribal Sovereignty Before and After Duro v. Reina, 38 FED. B. NEwS \& J. 70 (1991); Matthew L.M. Fletcher, $A$ Short History of Indian Law in the Supreme Court, 40 HUM. RTS. 3, 5 (2015) ("In recent decades, the Supreme Court has markedly shifted toward skepticism of tribal interests and tribal claims, and away from federal policies announced by Congress and the executive branch." (citing Wenona T. Singel, The First Federalists, 62 DRAKE L. REV. 775 (2014))); Charles Wilkinson, "Peoples Distinct From Others": The Making of Modern Indian Law, 2006 UTAH L. REV. 379, 384-85 (2006). This scholarly concern, however, has not produced a coherent framework for assessing why decisions about inherent tribal sovereignty should rest with the courts or Congress.

9. See Mary Kathryn Nagle, Standing Bear v. Crook: The Case for Equality Under Waaxe's Law, 45 CREIGHTON L. REV. 455, 468-69 (2012) ("This racially constructed political question doctrine would later give rise to what we now know as the plenary power doctrine. An important ramification of Lone Wolf $v$. Hitchcock is that whenever the Court applies the plenary power doctrine, it must defer to the other branches of federal government with respect to their treatment of Native Americans. Today the Cherokee Nation Court's political question doctrine still precludes Native Americans' access to the courts on account of their racial inferiority.") (footnotes omitted). 
criticized by a generation of Indian law scholars who view the doctrine as depriving tribes of meaningful judicial review and leaving tribes vulnerable to unchecked political whim. ${ }^{10}$ Similarly, many Indian law scholars view the plenary power doctrine - that Congress has expansive, virtually unlimited authority to regulate tribes - as a tool that fosters and formalizes the legal oppression of Indian people by an unchecked federal government. ${ }^{11}$ In embracing the combination of these doctrines, the Court has attempted to have it both ways: a kind of "heads I win; tails you lose" approach to questions of inherent tribal sovereignty.

Still, the Court has repeatedly made reference to a subset of retained, inherent internal rights of self-government that belong to the tribes, to the approval of many Indian law scholars. ${ }^{12}$ Thus, the legal paradox: While the Court acknowledges the plenary power of Congress over Indian affairs, it also acknowledges that a critical core of inherent tribal sovereignty endures. ${ }^{13}$ Yet, lacking a principled way to distinguish which inherent tribal powers endure and which may have been

10. See, e.g., 3 WILLIAM J. Rich, MOdern CONSTITUTIONAL LAW 347 (3d ed. 2011) ("The plenary power and political question doctrines permitted unbridled congressional authority that led to legendary patterns of abuse.”); DAVID E. WILKINS, AMERICAN INDIAN SOVEREIGNTY AND THE U.S. SUPREME COURT: THE MASKING OF JUSTICE 46 (1997) ("The political question doctrine warrants immediate analysis because it ranks alongside the plenary power concept as one of the most effective judicial strategies utilized by the Supreme Court to diminish and in some cases to eradicate tribal rights. But while plenary power may be defined in a constructive way - as exclusive or preemptive- to protect Indian rights from state advances, the political question construct has no such redeeming definitional value from a tribal standpoint."); Bethany R. Berger, "Power Over This Unfortunate Race": Race, Politics and Indian Law in United States v. Rogers, 45 WM. \&MARY L. REV. 1957, 2042 (2004) (describing the plenary power doctrine as "[o]ne of the most significant challenges to the idea of tribal sovereignty" and arguing that "[t]hrough most of the history of Indian policy, . . . the political question doctrine has been invoked successfully to shield congressional power from judicial review."); Philip P. Frickey, Doctrine, Context, Institutional Relationships, and Commentary: The Malaise of Federal Indian Law through the Lens of Lone Wolf, 38 TULSA L. REV. 5, 13 (2002) ("[W] hen Lone Wolf embraced the notion that congressional abrogation of an Indian treaty is a political question unresolvable in domestic courts, the Court left tribes without a remedy to prevent the abrogation and without hope of retrospective relief for the consequences of the abrogation unless they successfully beseeched the tender mercies of a later Congress."); Nell Jessup Newton, Federal Power Over Indians: Its Sources, Scope, and Limitations, 132 U. PA. L. REV. 195, 197 (1984) ("[E]xtraordinary deference to congressional power over Indians is closely related to the courts' failure to protect Indian tribal rights ....").

11. See Berger, supra note 10; Frickey, supra note 10.

12. See United States v. Wheeler, 435 U.S. 313, 322-24 (1978) (indicating that " $[t]$ he powers of Indian tribes are, in general, "inherent powers of a limited sovereignty which has never been extinguished" and that the "right of internal self-government includes the right to prescribe laws applicable to tribe members and to enforce those laws by criminal sanctions."), superseded by statute on other grounds as stated in United States v. Lara, 541 U.S. 193, 193 (2004); United States v. Mazurie, 419 U.S. 544, 557 (1975) (holding that tribes "are unique aggregations possessing attributes of sovereignty over both their members and their territory ... [and that they possess] ... 'the power of regulating their internal and social relations.").

13. Justice Thomas has called this apparent paradox of federal Indian law "schizophrenic." Lara, 541 U.S. at 219 (Thomas, J., concurring). 
implicitly divested by Congress, courts have failed to develop judicially manageable standards that are intelligible, determinate, and predictable.

The unsuccessful struggle for judicially manageable standards confirms that the task of defining inherent tribal sovereignty is simply not well suited to judicial inquiry. This is especially true given the backdrop of congressional plenary authority and the specter of the political question doctrine. The judicial inquiry into retained inherent tribal powers has failed to produce core, consistent principles from which a court could define a tribe's retained sovereignty. Where such principles are absent, the question of inherent tribal authority is not for the judiciary, but for the political branches.

The paradox motivating this discussion is the Court's willingness to accept Congress's plenary power when it is to the detriment of tribes, while asserting judicial review over congressional acts that benefit tribes. In essence, while the Court has suggested that the plenary power and political question doctrines have stripped it of a meaningful role in protecting tribes from congressional diminution, the Court has expressed no such qualms in claiming a role in reviewing congressional actions affirming tribal authority. While the judiciary has generally stepped away from the political question doctrine in other areas of law, we have seen courts struggling unsuccessfully to develop adequate, judicially manageable standards when deciding which inherent powers of sovereignty a tribe might retain. ${ }^{14}$ Given this judicial struggle and the resulting uncertainty for tribes and litigants, the political question doctrine may, indeed, have some application to the judicial treatment of inherent tribal authority. ${ }^{15}$

14. See, e.g., Montana v. United States, 450 U.S. 544, 565 (1981) (holding that tribes have been generally divested of inherent civil jurisdiction over non-Indians on fee lands, subject to certain exceptions); United States v. Wheeler, 435 U.S. 313, 326-29 (1978) (rejecting a Double Jeopardy challenge to successive federal and tribal criminal prosecutions on the grounds that tribal sovereignty is inherent rather than delegated); Oliphant v. Suquamish Indian Tribe, 435 U.S. 191, 195 (1978) (holding that tribes had been impliedly divested of inherent authority to prosecute nonIndians).

15. Arguably, the issue of Congress's plenary power to abrogate the power of tribes is much older than a century. Many, however, would trace this line of argument to Lone Wolf v. Hitchcock, where Justice White arguably reframed the history of tribes negotiating treaties with the U.S government as follows: "Plenary authority over the tribal relations of the Indians has been exercised by Congress from the beginning, and the power has always been deemed a political one, not subject to be controlled by the judicial department of the government." 187 U.S. 553, 565 (1903). Yet Justice White's reasoning itself also provides a defense that suggests that this way of thinking is hardly novel at all. He goes on to add:

Until the year 1871 the policy was pursued of dealing with the Indian tribes by means of treaties, and, of course, a moral obligation rested upon Congress to act in good faith in performing the stipulations entered into on its behalf. But, as with treaties made with foreign nations, the legislative power might pass laws in conflict with treaties made with the Indians. 
When the Court held that some degree of inherent authority could be divested not by treaty or statute, but by implication, it launched a jurisprudential inquiry into an essentially political question without objective, judicially manageable standards. ${ }^{16}$ The result - the implicit divestiture theory-has been an unprecedented aggrandizement of the role of the Court in federal Indian policy and a usurpation of the role of the political branches. Thus, the Court should disavow the implicit divestiture doctrine by treating questions about the extent to which inherent tribal authority has been extinguished as political questions that do not present justiciable controversies. Under this approach, tribes would have sovereign authority to act except where Congress has explicitly revoked that authority; in turn, congressional acts that extinguish, or affirm, particular aspects of tribal sovereignty would be unreviewable under the political question doctrine. Indeed, unless the Court is willing to reexamine the fundamental assumption of congressional plenary power and repudiate the political question doctrine, the Court should renounce its self-created role in setting the bounds of inherent tribal authority.

This Article proposes that the political question and plenary power doctrines should give Congress exclusive jurisdiction to decide questions of inherent tribal authority, or else tribes will continue to face a rigged coin toss in the courts. Courts should treat questions challenging inherent tribal authority similar to the way it treats questions challenging federal plenary power in Indian affairs: as political questions that do not present justiciable controversies. Thus, courts should presume that tribes have retained all inherent authority unless Congress has specifically and explicitly divested the tribe of a particular power. As a result, challenges by individuals who object to a tribe's exercise of authority as being outside the scope of inherent authority would be declared nonjusticiable, political questions - that is, unless Congress has explicitly delineated the dimunition or affirmation of the authority in question. ${ }^{17}$ Tribal challenges to Congress's ability to diminish inherent tribal authority would also continue to be treated as essentially political questions. This more consistent approach ultimately leaves the scope of inherent tribal authority in the hands of Congress. This result both flows ineluctably from the plenary powers doctrine and guarantees that these

Id. at 565-66 (citation omitted).

16. Oliphant, 435 U.S. at 195 (holding that tribes had been impliedly divested of inherent authority to criminally prosecute non-Indians).

17. As suggested in Delaware Tribal Business Committee v. Weeks, questions raising constitutional claims such as due process and equal protection would be justiciable. See 430 U.S. 73, 84 (1977). The Court suggested that the outer limit of congressional plenary power over Indian affairs is coextensive with the Constitution, explaining that the Indian affairs power is "of a plenary nature; but it is not absolute.” Id. (quoting United States v. Alcea Band of Tillamooks, 329 U.S. 40, 54 (1946)). 
critical policy decisions, which are fundamentally political rather than judicial, are made by the politically accountable Congress, leaving courts to interpret and apply jurisdictional statutes rather than formulate federal Indian policy.

The argument proposed in this Article builds upon my earlier work assessing the comparative institutional competency of Congress and the courts with regard to questions of inherent tribal authority. ${ }^{18}$ Under a comparative institutional competency analysis, federal recognition of the metes and bounds of inherent tribal sovereignty, to the extent it is a federal policy question, ought to be set by the political branches and not undermined by the judiciary. ${ }^{19}$ This Article proposes a fundamental shift in the concept of both the plenary power and the political question doctrines as applied to federal Indian law. In doing so, it runs counter to the weight of existing scholarly commentary and to the Court's precedent as currently understood. Scholars have traditionally rejected or critiqued both the plenary power doctrine and the political question doctrine in Indian affairs because they leave a discrete and insular minority vulnerable to political whims. ${ }^{20}$ The critique has generally envisioned the Court as a countermajoritarian bastion standing between the tyranny of the majority and the tribes. This Article reexamines that assumption and the application of these doctrines in the current legal environment. The Court's persistent embrace of the plenary power doctrine, in combination with its application of its theory that tribes may have lost powers by implication (implicit divesture), has proven to be an untenable combination for tribes, litigants, and courts. With no reform of the plenary power doctrine on the horizon, tribes and litigants must deal with reality: A legal landscape characterized by inconsistent applications of the plenary power and political question doctrines. This Article thus challenges long-held assumptions about these fundamental doctrines of federal Indian law and poses important questions about the role of the courts and Congress, as well as the future of inherent tribal sovereignty.

18. See Michalyn Steele, Comparative Institutional Competency and Sovereignty in Indian Affairs, 85 U. COLO. L. REV. 759 (2014) (arguing that traditional comparative institutional competency considerations suggest that Congress, rather than the courts, ought to decide questions of inherent tribal authority).

19. Id.

20. See, e.g., Philip J. Prygoski, War as the Prevailing Metaphor in Federal Indian Law Jurisprudence: An Exercise in Judicial Activism, 14 T.M. COOLEY L. REV. 491, 520 (1997) ("The . . combination of the Plenary Power and Political Question Doctrines was to give Congress an absolute, unchecked power to regulate all affairs with the Indians."); Joseph William Singer, Lone Wolf, or How to Take Property by Calling It a "Mere Change in the Form of Investment", 38 TULSA L. REV. 37,37 (2002) (calling Lone Wolf the "Indians' Dred Scott Decision" for placing Indians beyond reach of the constitution (quoting Sioux Nation of Indians v. United States, 601 F.2d 1157, 1173 (Ct. Cl. 1979) (Nichols, J., concurring))). 
Part I of this Article considers the doctrine of tribal sovereignty in general, and the doctrine of inherent tribal authority in the courts in particular. Part II examines the legacy of the political question doctrine in Indian affairs and explores the origins and consequences of judicial review in federal Indian law. Part III examines the Court's development of the implicit divestiture doctrine. Part IV extends traditional political question considerations to assertions of inherent tribal authority and evaluates the effects and limits of applying the political question doctrine in this context. The Article concludes by recommending that the Court reorder its Indian law jurisprudence in a manner that results in a more consistent and principled application of the political question and plenary power doctrines.

\section{SOVEREIGNTY ANDTHE INHERENT POWER OF TRIBES}

Legal theorists have sought a working definition of sovereignty for generations without arriving at consensus. ${ }^{21}$ Characterizing the complexity of the debate, legal philosopher John Alan Cohan writes that "sovereignty is anything but simple. There is disagreement as to the nature of sovereignty, whether it is a relevant sort of concept in geopolitics, and whether there is a one-size-fits all definition." ${ }^{22}$ This debate continues in an increasingly complex and globalized world. Louis Henkin, former president of the American Society for International Law,

21. See e.g., JOHN AUSTIN, LECTURES ON JURISPRUDENCE: THE PHILOSOPHY OF POSITIVE LAW 116-209 (Robert Campbell ed., 1875); JOHN CHIPMAN GRAY, THE NATURE AND SOURCES OF THE LAW 74-79 (Roland Gray ed., 2d ed. 1921); THOMAS HOBBES, LEVIATHAN, OR, THE MATTER, FORM AND POWER OF A COMMONWEALTH, ECCLESIASTICAL AND CIVIL 84 (2d ed. George Routledge \& Sons 1886) (1651) (arguing that obedience to a sovereign is the price paid for legal order and protection); JOHN LOCKE, TwO TREATISES OF GOVERNMENT 251-52 (Peter Laslett ed., Cambridge Univ. Press 1988) (maintaining that a system of enforceable rightseither through courts or threat of rebellion-is a necessary check on sovereignty); SAINT AUGUSTINE, CITY OF GOD 88 (Image Books 1958) (426) ("In the absence of justice, what is sovereignty but organized brigandage?"). Indeed, the arguments about the nature of sovereignty are still hotly debated. See, e.g., RONALD DWORKIN, LAW's EMPIRE 33-35 (1986); H.L.A. HART, THE CONCEPT OF LAW passim (1961); CORNELIUS F. MURPHY, JR., MODERN LEGAL PHILOSOPHY: THE TENSION BETWEEN EXPERIENTIAL AND ABSTRACT THOUGHT 11-17 (1978); see also John Alan Cohan, Sovereignty in a Postsovereign World, 18 FLA. J. INT'L L. 907, 908-09 (2006) (noting that "[e]arly on, sovereignty was the simple Hobbesian idea that the sovereign had an undefeatable ability to determine the law and to have those determinations obeyed. . . Traditionally, sovereignty vested the monarch with powers that would be seen as absolute in the legal and political theory of the time. There was no other institution that could erode the sovereign will."); Paul W. Kahn, The Question of Sovereignty, 40 STAN. J. INT'L L. 259, 259 (2004) ("Sovereignty has become an essentially contested concept. What had been an ontological concept is attacked today from the perspective of a global functionalism that emphasizes state interdependence in the face of common problems."); W. Michael Reisman, Sovereignty and Human Rights in Contemporary International Law, 84 AM. J. INT'L L. 866 (1990) (discussing different historical meanings of "sovereignty").

22. Cohan, supra note 21, at 909. 
is reported to have suggested that "polite or educated society . . . banish[]" the word as contributing nothing meaningful to law. ${ }^{23}$

Tribal sovereignty is perhaps even more fraught and contentious. ${ }^{24}$ The federal-tribal relationship seems to be without a good model in other sovereign relations. ${ }^{25}$ The United States has asserted vast powers over tribes, yet has simultaneously proclaimed its respect for the principle that tribes retain inherent governing powers that predate the Constitution, and have never been extinguished. The federal government has claimed an intensely micromanagerial role in tribal life, but it has declared its official policy as promoting tribal self-determination. At the same time, tribes have both declared themselves self-governing sovereigns and laid claim as beneficiaries of the federal-tribal trust relationship.

To be sure, tribes are no longer possessed of the "full attributes" of sovereignty, having been "necessarily divested ... of some aspects of the sovereignty which they had previously exercised" by treaty and by statute. ${ }^{26}$ But diminished sovereignty is not the same thing as no sovereignty. Justice Thomas has questioned how Congress' expansive power to regulate tribes coexists with the notion of "tribal sovereignty" without rendering sovereignty "a nullity." ${ }^{27}$ In contrast, this Part argues in favor of a spectrum of sovereignty that allows for the coexistence of two parallel sovereigns, related and cooperative, as envisioned by the Two Row

23. See id. ("Today, sovereignty is anything but simple. There is disagreement as to the nature of sovereignty, whether it is a relevant sort of concept in geopolitics, and whether there is a one-sizefits all definition.... [S]overeignty [is] a complex subject."). Professor Cohan also notes, "In 1993, Louis Henkin, the then-president of the American Society for International Law, urged that the word 'sovereignty' be banished from polite or educated society" and that the concept of sovereignty "has been criticized as being of more value for oratory purposes and persuasion than for science and law." Id. at 908 (citing MiCHAEL Ross Fowler \& JULIE MARIE BUNCK, LAW, POWER, AND THE SOVEREIGN STATE 21 (1995) and Notes from the President, ASIL NEWSL. 1, 6 (1993)).

24. See, e.g., WIKINS, supra note 10, at 21; Robert N. Clinton, Isolated in Their Own Country: A Defense of Federal Protection of Indian Autonomy and Self-Government, 33 STAN. L. REV. 979, 996-1001 (1981); Richard B. Collins, Indian Consent to American Government, 31 ARIZ. L. REV. 365 (1989); Gary D. Meyers, Different Sides of the Same Coin: A Comparative View of Indian Hunting and Fishing Rights in the United States and Canada, 10 UCLA J. ENVTL. L. \& POL'Y. 67, 89 (1991); Newton, supra note 10, at 261-67; Mary Christina Wood, Indian Land and the Promise of Native Sovereignty: The Trust Doctrine Revisited, 1994 UTAH L. REV. 1471 (1994) [hereinafter Wood, Indian Land]; Mary Christina Wood, Protecting the Attributes of Native Sovereignty: A New Trust Paradigm for Federal Actions Affecting Tribal Lands and Resources, 1995 UTAH L. REV. 109 (1995).

25. See Wood, Indian Land, supra note 24, at 1498 ("It has often been said that the relationship of Indian tribes to the federal government is unlike any other, or sui generis.").

26. United States v. Wheeler, 435 U.S. 313, 323 (1978) (quoting United States v. Kagama, 118 U.S. $375,381(1886))$.

27. United States v. Lara, 541 U.S. 193, 215 (2004); but see Cohan, supra note 21, at 909 ("Today, sovereignty is anything but simple. There is disagreement as to the nature of sovereignty, whether it is a relevant sort of concept in geopolitics, and whether there is a one-size-fits all definition. ... [S]overeignty [is] a complex subject"). 
Wampum, and rejects Justice Thomas' absolutist view of all-or-nothing sovereignty, whereby any diminishment of tribal sovereignty renders the concept a nullity. Part I.A provides an overview of the nature of tribes as sovereigns. Part I.B sets forth the doctrine of inherent tribal authority under law as vital rather than null.

\section{A. The Nature of Tribes as Sovereigns}

Chief Justice Marshall made clear in the so-called "Marshall Trilogy" of early Indian law cases that the United States had inherited and would apply the doctrine of discovery in its relations with Indian tribes. ${ }^{28}$ Under this doctrine, tribes and tribal people were considered inferior in sovereignty and character. ${ }^{29}$ Yet, tribes still maintained some degree of sovereignty.

In deciding whether the Cherokee Nation was or was not a "foreign nation" for constitutional purposes, Chief Justice Marshall wrestled with the nature of tribes as sovereigns. He concluded that tribes were not foreign sovereigns but could be denominated "domestic dependent nations," retaining some measurethough a diminished measure to be sure - of their aboriginal sovereignty. ${ }^{30}$ The Court affirmed that the Cherokee Nation had the character of a state in the sense

28. The "Marshall Trilogy" includes three foundational cases authored by Chief Justice Marshall that established the earliest principles of federal Indian law: Worcester v. Georgia, 31 U.S. (6 Pet.) 515 (1832); Cherokee Nation v. Georgia, 30 U.S. (5 Pet.) 1 (1831); and Johnson v. M'Intosh, 21 U.S. (8 Wheat.) 543 (1823).

29. See Cherokee Nation, 30 U.S. (5 Pet.) at 15 (speaking of the Cherokee Nation, Marshall said, "A people once numerous, powerfil, and truly independent, found by our ancestors in the quiet and uncontrolled possession of an ample domain, gradually sinking beneath our superior policy, our arts and our arms, have yielded their lands by successive treaties, each of which contains a solemn guarantee of the residue....").

30. Id. at 17. In dissent, Justice Thompson wrote that the superior sovereignty, or power, of the United States does not diminish the sovereign nature of the Indian tribes:

Every nation that governs itself, under what form soever, without any dependence on a foreign power, is a sovereign state. Its rights are naturally the same as those of any other state. Such are moral persons who live together in a natural society, under the law of nations... . [I]t must govern itself by its own authority and laws. We ought, therefore, to reckon in the number of sovereigns those states that have bound themselves to another more powerful, although by an unequal alliance. The conditions of these unequal alliances may be infinitely varied; but whatever they are, provided the inferior ally reserves to itself the sovereignty or the right to govern its own body, it ought to be considered an independent state. Consequently, a weak state, that, in order to provide for its safety, places itself under the protection of a more powerful one, without stripping itself of the right of government and sovereignty, does not cease on this account to be placed among the sovereigns who acknowledge no other power.

Id. at 53 (Thomas, J., dissenting). 
of being self-governing and separate from the United States. ${ }^{31}$ As Chief Justice Marshall noted in Cherokee Nation v. Georgia, the Commerce Clause of the U.S. Constitution presumes a sovereign character of Indian tribes, as it groups them with states and foreign nations-in other words, as governments with and among whom Congress could regulate commerce. ${ }^{32}$

Tribes have been recognized, as with other sovereign entities, as competent partners in treaty. Chief Justice Marshall declared that " $[h]$ owever extravagant the pretension of converting the discovery of an inhabited country into conquest may appear," the American court system, the "courts of the conqueror," is bound to implement the doctrine of discovery and the concomitant principles governing relations with the Indian nations that were inherited from European legal progenitors. ${ }^{33}$ Construing the Cherokee treaty with the United States, Chief Justice Marshall concluded that "the only inference to be drawn ... is that the United States considered the Cherokees as a nation." ${ }^{34}$ Nevertheless, he found some justification for the United States' assertion of superior sovereignty in "the character and habits of the people whose rights have been wrested from them.... To leave them in possession of their country, was to leave the country a wilderness." ${ }^{35}$ Ultimately, the underlying principle synthesized in these early cases remains vital: Tribes are governments with some degree of authority over its people and territory. ${ }^{36}$

31. Id. at 12,14 (majority opinion).

32. Id. at 18; see also U.S. CONST. art I, § 8, cl. 3 .

33. Johnson, 21 U.S. (8 Wheat.) at 588, 591.

34. Worcester v. Georgia, 31 U.S. (6 Pet.) 515, 518 (1832).

35. Jobnson, 21 U.S. (8 Wheat.) at 589-90. Scholars have challenged Marshall's formulation and rationale as fundamentally flawed by its racist underpinnings. See Matthew L.M. Fletcher, The Iron Cold of the Marshall Trilogy, 82 N.D. L. REV. 627, 674 (2006) ("No discussion of the Trilogy is complete without a full reckoning of the racism inherent in the holdings or the racism of the reasoning behind the holdings."); Philip P. Frickey, Domesticating Federal Indian Law, 81 MINN. L. REV. 31, 95 (1996) ("Need we, a century and one-half later, in a world considerably less sanguine about colonization, settle for this little?”); Philip P. Frickey, Marshalling Past and Present: Colonialism, Constitutionalism, and Interpretation in Federal Indian Law, 107 HARV. L. REV. 381 (1993) [hereinafter Frickey, Marshalling] (discussing the influence of colonialism in the Marshall Trilogy).

36. This conception of tribes as self-governing and as having authority over people and territory has not been the sole province of the judiciary. A Senate Judiciary Report from 1879 said: We have considered [Indian tribes] as invested with the right of self-government and jurisdiction over the persons and property within the limits of the territory they occupy, except so far as that jurisdiction has been restrained and abridged by treaty or act of Congress. Subject to the supervisory control of the Federal Government, they may enact the requisite legislation to maintain peace and good order, improve their condition, establish school systems, and aid their people in their efforts to acquire the arts of civilized life.... 
Recognizing the existence of some enduring tribal sovereignty as an initial matter leaves open the question of which particular governing powers remain and over whom those powers may be exercised. When disputes arise as to the scope of inherent tribal authority, for example, critical questions also arise about how and by whom these disputes are to be settled. These difficult and vital questions have beguiled courts and commentators, and they are at the heart of this Article's inquiry.

\section{B. The Inherent Tribal Sovereignty Doctrine}

The Supreme Court has affirmed that tribal sovereignty does not derive from a delegation of federal authority, but endures as aboriginal authority that predates the Constitution and has never been extinguished. ${ }^{37}$ For example, in Talton v. Mayes, the Supreme Court considered the question of whether a tribal court criminal conviction could be challenged by the defendant because the Fifth Amendment grand jury requirements had not been satisfied in the proceedings. ${ }^{38}$ The outcome turned on "whether the powers of local government exercised by the Cherokee nation are Federal powers created by and springing from the Constitution of the United States, and hence controlled by the Fifth Amendment to that Constitution." ${ }^{39}$ The Court found that the power of government exercised by the tribe "existed prior to the Constitution" and was not operated upon by the Fifth Amendment, even though the tribe itself was subject to the "supreme legislative authority of the United States." ${ }^{40}$

Similarly, in 1978 the Court found in United States v. Wheeler that, for matters arising from the same set of facts, a criminal prosecution in both tribal and federal courts presented no Double Jeopardy concern. ${ }^{41}$ The source of tribal criminal jurisdiction was not a delegation from the federal government, but rather, inherent to tribal sovereignty. The Court held that the "powers of Indian tribes are, in general, "inherent powers of a limited sovereignty which has never been extinguished."'42

S. Rep. No. 698-45, at 1-2 (1879), quoted in Merrion v. Jicarilla Apache Tribe, 455 U.S. 130, 140 (1982)

37. See United States v. Wheeler, 435 U.S. 313, 323-24 (1978); Talton v. Mayes, 163 U.S. 376, $382-$ 83 (1896).

38. See 163 U.S. at 376.

39. Id. at 382 .

40. Id. at 384 .

41. 435 U.S. at 329-30.

42. Id. at 322 (citing FELIX S. COHEN, HANDBOOK OF FEDERAL INDIAN LAW 122 (1945)). 
In Wheeler, the Court described tribes as "unique aggregations possessing attributes of sovereignty over both their members and their territory" and held that tribes "have not given up their full sovereignty." ${ }^{3}$ Moreover, the power of governance inherent to tribes was not analogous to the power of self-government inherent to civic organizations or religious organizations, a kind of right to organization or assembly: Tribes "are a good deal more than 'private, voluntary organizations."'44

The next Part outlines the way that the plenary power and the political question doctrines in Indian law may bear upon the role of the judiciary.

\section{THELEGACYOF LONEWOLF}

The story of federal Indian law is a study in the art of using the shards of adverse precedent to cobble together enduring arguments and principles from what remains. For example, although tribal interests did not prevail in Chief Justice Marshall's landmark decisions, Johnson v. MIntosh and Cherokee Nation v. Georgia, those decisions have come to undergird the precedential foundation that tribes are sovereigns or, as Chief Justice Marshall stated it, domestic dependent nations with rights to self-government within the American system. While Chief Justice Marshall coined the term to differentiate tribes as sovereigns from foreign nations, tribal advocates have built upon the concept of tribal sovereignty found in these early losses to advance tribal interests.

In terms of cases that epitomize painful losses to tribal interests, there is hardly one more universally reviled by tribal advocates than Lone Wolf v. Hitchcock, a case holding that tribes did not have access to judicial review of Congress's decision to unilaterally abrogate terms of a treaty. ${ }^{45}$ The consequences of Lone Wolf and its progeny, discussed more fully below, have been described as "mark[ing] a low point in American jurisprudence defining the political and legal status of Indian nations and their members within the boundaries of the United States." ${ }^{\prime 6}$ The Court declined to review the judgment of Congress changing the terms of a treaty with the Kiowa Nation, and refused to hear the tribe's petition to

\footnotetext{
43. Id. at 323 .

44. Id. (citing United States v. Mazurie, 419 U.S. 544, 557 (1975))

45. See 187 U.S. 553 (1903); see also Robert N. Clinton, There Is No Federal Supremacy Clause for Indian Tribes, 34 ARIZ. ST. L.J. 113, 182 (2002) ("One federal judge rightly said of this decision, " $[t]$ he day Lone Wolf was handed down . . . might be called one of the blackest days in the history of the American Indian ...." (quoting Sioux Nation of Indians v. United States, 601 F.2d 1157, 1173 (Ct. Cl. 1979) (Nichols, J., concurring))).

46. WALTER R. ECHO-HAWK, IN THE COURTS OF THE CONQUEROR: THE 10 WORST INDIAN LAW CASES EVER DECIDED 180 (2010).
} 
enforce the treaty and its allegation of bad faith. ${ }^{47}$ The Court determined that the tribe should resort to Congress, not the courts, to address such questions. ${ }^{48}$

As introduced in Lone Wolf, the interplay of the plenary power and political question doctrines in federal Indian law has resulted in uneven access to judicial review and Congress's virtually unchecked political power over Indian affairs. However, these doctrines have not prevented the courts from accepting jurisdiction over cases challenging the exercise of inherent tribal powers, often to the detriment of tribal authority. This Part looks at the origins of each of these doctrines.

\section{A. The Plenary Power Doctrine}

Congress has long been recognized as having plenary, but not absolute, power in the realm of Indian affairs. ${ }^{49}$ Courts and scholars have postulated a number of possible sources of this broad power. One potential source can be traced to the text of the Indian Commerce Clause, though no particular nexus with commerce has been required to legitimize the power. ${ }^{50}$ The Treaty Clause, empowering the Executive to negotiate and the Senate to ratify treaties, has also been viewed as a potential source; ${ }^{51}$ United States v. Lara, as another. ${ }^{52}$ In the La$r a$ decision, the majority suggests, in dicta, that the plenary power of Congress over Indian affairs may also have roots in the "preconstitutional powers" described in United States v. Curtiss-Wright Export Corp. ${ }^{53}$ that are concomitants of sovereignty, or in other words, inherent powers. Indeed, in a number of important contexts, the federal government has asserted broad powers, not necessarily as enumerated constitutional powers delegated from the people or the states, but rather, as extraconstitutional "necessary concomitants of nationality." These powers have traditionally included the powers to conduct foreign affairs, to provide for national security, to regulate immigration, and to negotiate with

47. See Lone Wolf, 187 U.S. at $567-68$.

48. In Delaware Tribal Business Committee v. Weeks, however, which modifies but does not overrule Lone Wolf, the Court suggests that Congress could not violate the Constitution in the exercise of its Indian affairs power and, were Congress to attempt to do so, the judiciary might entertain such a question; nevertheless, no constitutional question had been presented in Weeks. 430 U.S. 73, 83-84 (1977).

49. See, e.g., id. at 84 ("The power of Congress over Indian affairs may be of a plenary nature; but it is not absolute." (quoting United States v. Alcea Band of Tillamooks, 329 U.S. 40, 54 (1946) (plurality opinion))).

50. Matthew L.M. Fletcher, Preconstitutional Federal Power, 82 TUL. L. REV. 509, 524-25 (2007).

51. U.SCONST. art I, §2, cl. 2.

52. See United States v. Lara, 541 U.S. 193, 201 (2004).

53. United States v. Curtiss-Wright Export Corp., 299 U.S. 304, 315-22 (1936).

54. Id. 
the Indian tribes. ${ }^{55}$ These plenary powers are generally the province of the political branches, and the judiciary has therefore frequently deferred to the political branches to police itself in the conduct of these powers. ${ }^{56}$

As noted above, Lone Wolf represents the apex of judicial deference in the realm of Indian affairs. In rejecting the claim of the Kiowa Nation that the treaty had been altered by fraud and misrepresentation, the Court held that it could not consider the tribe's claims because of the breadth of Congress's legislative power: ${ }^{57}$

We must presume that Congress acted in perfect good faith in the dealings with the Indians of which complaint is made, and that the legislative branch of the government exercised its best judgment in the premises. In any event, as Congress possessed full power in the matter, the judiciary cannot question or inquire into the motives which prompted the enactment of this legislation. If injury was occasioned ... by the use made by Congress of its power, relief must be sought by an appeal to that body for redress and not to the courts. ${ }^{58}$

In some respects, the absolutist principles announced in Lone Wolf have been modified in important ways by cases like Delaware Tribal Business Committee v. Weeks. ${ }^{59}$ Congress, for example, is constrained by the Constitution in the exercise of the Indian affairs power, as it is in all of its enactments. In Delaware Tribal Business Committee, the Court explained that plenary power over Indian affairs is indeed "plenary," but "not absolute" because the plenary power doctrine does not authorize Congress to otherwise violate the Constitution. ${ }^{60}$ The Court allows the theoretical possibility that it may find the plenary power exceeded if Congress were to expressly transgress some other constitutional stricture, such as the due process clause, in the exercise of its Indian affairs power. ${ }^{61}$ Short of a justiciable constitutional claim, however, Indian tribes and Indian people are at the mercy of the political process. Thus, the legacy of a default rule of judicial deference to Congress - resting on the principles of plenary power and, explicitly or

55. Fletcher, supra note 50, at 514-30.

56. Id:; see also Lone Wolf v. Hitchcock, 187 U.S. 553, 567-68 (1903).

57. Lone Wolf, 187 U.S. at 567-68.

58. Id. at 568 .

59. Del. Tribal Bus. Comm. v. Weeks, 430 U.S. 73, 84 (1977).

60. See $i d$. at 84 (observing that the Court would "scrutiniz[e] Indian legislation to determine whether it violates the equal protection component of the Fifth Amendment" and that "[ $t]$ he power of Congress over Indian affairs may be of a plenary nature; but it is not absolute" (quoting United States v. Alcea Band of'Tillamooks, 329 U.S. 40, 54 (1946) (plurality opinion))).

61. See id. 
not, on the political question doctrine-disappointingly continues. To date, the limits on plenary power over Indian affairs exist more in theory than in fact.

In practice, this has meant that Congress has had a free hand to legislate and regulate with regard to Indian affairs, with mixed results. Congress has enacted legislation intended to empower tribes, such as the Indian Self-Determination Act, the Tribal Law and Order Act, and the Indian Healthcare Improvement Act; Congress has also acted to the detriment of tribal self-governance through termination acts and unilateral treaty abrogation. ${ }^{62}$ Absent an express constitutional claim, the judiciary has not provided a check on Congress's plenary power and, in fact, has upheld Congress's authority without a probing inquiry into the sources or consequences of such broad federal power.

Indian law scholars have pushed back on the plenary power doctrine with principled criticism for decades. Some have argued that the virtually unbridled federal power over Indians has been a tool of oppression without a judicial check, and that the judiciary has stood idly by rather than step in on behalf of the beleaguered political and ethnic minority. ${ }^{63}$ Others have acknowledged that the plenary power doctrine - whatever its origins or advisability — seems to be settled law, and have advocated that tribes engage in and influence the political process to shape law and policy. ${ }^{64}$

And so, despite strong scholarly objections, it seems likely that the plenary power doctrine is here to stay. The judiciary seems unlikely to upend the longstanding principle, despite the concerns expressed by Justice Thomas, and Congress seems even more unlikely to restrict its own broad power, either through express legislation or principled self-restraint. As a result, it is worth exploring how the political question doctrine ought to interact with the existing plenary power doctrine in Indian affairs.

62. Congress pursued a policy of legislative termination of the federal-tribal relationship and dissolution of the federal trust responsibility, voting to terminate 70 tribes in 1954. COHEN's HANDBOOK OF FEDERAL INDIAN LAW 94-95 (Nell Jessup Newton et al. eds., Am. Indian L. Ctr. 2005) (1941).

63. See, e.g., Clinton, supra note 45, at 163-64 (arguing that the plenary power doctrine "constitutes a racist American relic of 'white man's burden' arguments employed to justify American colonialism" and, rather than representing reasoned constitutional analysis, is "an unprincipled assertion of raw federal authority based on nothing more than the naked power to effectuate it").

64. See, e.g., Kirsten Matoy Carlson, Congress and Indians, 86 U. COLO. L. REV. 77 (2015) (analyzing congressional action related to Indian tribes and finding evidence of tribal political influence); Fletcher, supra note 50, at 524 ("While plenary power once created untold hardships for Indian people, Congress had lately begun using its plenary power, in most instances, to enact statutes for the benefit of Indian tribes and Indian people. Undermining the theoretical foundations of federal plenary power might serve to limit federal authority over Indian affairs, but it might also destroy much of what Indian people and tribes relied upon as their best hopes for a remedy."). 


\section{B. The Political Question Doctrine}

The judicial power over cases and controversies has been limited when the question presented concerns "subject matter that the Court deems to be inappropriate for judicial review." ${ }^{65}$ Whether the justiciability of so-called political questions is a constitutional or prudential limit is of course subject to great debate. The doctrine seems rooted in both the inherent limitations on the judicial function and in constitutional separation of powers doctrine. ${ }^{66}$

The Court has identified, in such cases as Baker v. Carr, characteristics of political questions, any one of which may signal the presence of a political question. ${ }^{67}$ These so-called Baker factors include:

[A] textually demonstrable constitutional commitment of the issue to a coordinate political department; or a lack of judicially discoverable and manageable standards for resolving it; or the impossibility of deciding without an initial policy determination of a kind clearly for nonjudicial discretion; or the impossibility of a court's undertaking independent resolution without expressing lack of the respect due $\mathrm{co}^{-}$ ordinate branches of government; or an unusual need for unquestioning adherence to a political decision already made; or the potentiality of embarrassment from multifarious pronouncements by various departments on one question. ${ }^{68}$

But these Baker factors themselves have been criticized as vague and imprecise. ${ }^{69}$ Nonetheless, the Court in Baker examined the kinds of cases that have typically raised political question concerns. Depending on the particulars, such matters may include cases and determinations involving foreign relations and the dates of hostilities which "frequently turn on standards that defy judicial application, or involve the exercise of a discretion demonstrably committed to the executive or legislature."70 According to Erwin Chemerinsky, the Court has found the following matters to typically involve political questions: "[R]epublican form of government clause and the electoral process, foreign affairs, Congress' ability to regulate its internal processes, the process for ratifying constitutional amend-

65. Erwin Chemerinsky, Constitutional LAW: Principles AND Policies 130 (4th ed. 2011).

66. See United States v. Cannon, 642 F.2d 1373, 1378-79 (D.C. Cir. 1981).

67. 369 U.S. 186, 217 (1962).

68. Id.

69. See Flast v. Cohen, 392 U.S. 83, 94 (1968) (observing that the construction of "cases" and "controversies" has "an iceberg quality, containing beneath their surface simplicity submerged complexities which go to the very heart of our constitutional form of government").

70. Baker, 369 U.S. at 211. 
ments, instances where the federal court cannot shape effective equitable relief, and the impeachment process." ${ }^{\text {"1 }}$ In addition, the Court has observed that while there is "no blanket rule" regarding a judicial consideration of "whether Indians are recognized as a tribe" the question contains "familiar attributes of political questions." ${ }^{\prime \prime 2}$ These categories of cases that have been identified share some characteristics that make them "beyond judicial cognizance."

The historical and textual ties empower Congress, rather than the courts, as the keeper of federal plenary power over Indian affairs. Thus, there is at least a colorable argument that it is for Congress, rather than the courts, to determine the scope of inherent tribal authority, and that the implicit divestiture inquiry invades that legislative function and usurps policy determinations that belong exclusively to the political branches.

\section{IMPLICIT DIVESTITURE AND THE INHERENT TRIBAL SOVEREIGNTY DOCTRINE IN THE SUPREME COURT}

Recent opinions from the Supreme Court have signaled an interest on the part of some Justices to revisit the longstanding, foundational principles of inherent tribal sovereignty. ${ }^{74}$ This Part examines the Supreme Court's development of the implicit divestiture doctrine and the modern court's treatment of inherent tribal sovereignty.

The principal decision analyzed in this Part is United States v. Lara, a 2004 case in which the Court considered whether Congress could recognize and affirm the inherent authority of tribes to exercise criminal jurisdiction over nonmember Indians. ${ }^{75}$ The case arose following the Court's decision in Duro v. Reina, which held that tribes were implicitly divested of criminal jurisdiction over all but their own members, including so-called "non-member Indians" as well as nonIndians. ${ }^{76}$

In response to Duro, Congress amended the Indian Civil Rights Act in 1991 by "recognizing" and "affirming" inherent tribal authority to exercise criminal jurisdiction over all Indians without regard to tribal affiliation. Congress left

71. CHEMERINSKY, supra note 65, at 133.

72. Baker, 369 U.S. at 215 (citing United States v. Holliday, 70 U.S. (3 Wall.) 407, 419 (1865))

73. Id. at 211 (noting that it is "error to suppose that every case or controversy which touches foreign relations lies beyond judicial cognizance").

74. See United States v. Lara, 541 U.S. 193, 226-31 (2004) (Souter, J., dissenting) (suggesting that the powers of criminal prosecution exercised by tribes bear the hallmarks of delegated federal powers rather than of unextinguished inherent sovereignty).

75. See id. (majority opinion).

76. Duro v. Reina, 495 U.S. 676, 687 (1990); see also Oliphant v. Suquamish Indian Tribe, 435 U.S. 191, 195 (1978). 
undisturbed Oliphant's holding that divested tribes' authority to exercise criminal jurisdiction over non-Indians. ${ }^{77}$ Lara presented a challenge to the authority of Congress to recognize and affirm inherent tribal authority despite the previous Court's pronouncement that such authority had been implicitly divested. ${ }^{78}$ The Court affirmed the "broad general powers to legislate in respect to Indian tribes" exercised by Congress in the field of Indian affairs. ${ }^{79}$ In so doing, it upheld the intent of Congress to affirm that the source of power exercised by the tribes in this instance was inherent tribal sovereignty, rather than delegated federal authority. ${ }^{80}$

Although Justice Thomas concurred in the judgment as a matter of stare decisis, he wrote that he did "not necessarily agree that the tribes have any residual inherent sovereignty or that Congress is the constitutionally-appropriate branch to make adjustments to sovereignty." ${ }^{\prime 1}$ Justice Thomas suggested that Wheeler, which affirmed the inherent nature of tribal sovereignty, may have been incorrectly decided. ${ }^{82} \mathrm{He}$ argued that what he called the "residual-sovereignty theory" ignores that tribes are "not part of [the] constitutional order, and their sovereignty is not guaranteed by it." ${ }^{33}$ Calling federal Indian policy "schizophrenic," Justice Thomas observed that it "is quite arguably the essence of sovereignty not to exist merely at the whim of an external government." 84

Justice Thomas also took issue with the majority's reasoning with respect to Congress's power to alter the bounds of inherent tribal authority. While he was willing to defer in Lara to the calculus of the political branch with respect to inherent tribal authority, he criticized the majority for failing to posit a convincing theory of the source of Congress' Indian affairs power. ${ }^{86}$ Justice Thomas asserted that the Court did not identify any enumerated power for regulating Indian affairs, but instead cited historical examples of the assertion of such power. ${ }^{87}$ Justice Thomas asserted: "The Federal Government cannot simultaneously claim power

77. See Oliphant, 435 U.S. at 195. But see Violence Against Women Reauthorization Act of 2013, Pub. L. No. 113-4, 127 Stat. 54 (2013) (codified as amended at 25 U.S.C. $§ 1304(b)(1)$ (2012)) (recognizing and affirming a limited criminal jurisdiction over "all persons" for crimes of domestic violence in Indian country).

78. Lara, 541 U.S. at $193-94$.

79. Id. at 200.

80. See id. at 199

81. Id. at 224 (Thomas, J., concurring in judgment).

82. Id. at 217.

83. Id. at 218-19.

84. Id. at 218.

85. Id. at 223-24.

86. Id. at 224 .

87. Id:; see also Adoptive Couple v. Baby Girl, 133 S. Ct. 2552, 2566-67 (2013) (challenging the doctrine of Congress's plenary power over Indian affairs under the Indian Commerce Clause). 
to regulate virtually every aspect of the tribes through ordinary domestic legislation and also maintain that the tribes possess anything resembling "sovereignty."

Philip P. Frickey called the Thomas concurrence in Lara "the most candid statement by a Supreme Court Justice on federal Indian law since the Marshall Court." Though disputing Justice Thomas's conclusions, Frickey said that he performed an important service by raising the questions. ${ }^{89}$ Although scholars have responded vigorously to Justice Thomas's rejection in Lara of the premises of the doctrine of inherent tribal sovereignty, he is not alone in his skepticism of the doctrine..$^{90}$

In the same case, Justice Souter dissented from the majority's affirmation of the congressional action overturning Duro. For Justice Souter, the holdings of Oliphant v. Suquamish Tribe ${ }^{91}$ and Duro, which state that tribes have criminal jurisdiction only over their own members, were constitutional in nature and could not be altered by legislative affirmation of inherent authority. He wrote that "while this is not the place to reexamine the concept of dual sovereignty itself, there is certainly no reason to adopt a canon of broad construction calling for maximum application of the doctrine. ${ }^{\prime 2}$ The only way for tribes to exercise inherent sovereignty to prosecute nonmembers of the tribe following Duro, according to Justice Souter, would be for Congress to grant the tribes total independence, as it did with the Philippines, or "to repudiate its existing doctrine of [tribes'] dependent sovereignty." 93

88. Lara, 541 U.S. at 225 (Thomas, J., concurring); see also id. at 224 ("Although I do not necessarily agree that the tribes have any residual inherent sovereignty or that Congress is the constitutionally appropriate branch to make adjustments to sovereignty, . . . it is important to recognize the logical implications of these assumptions.").

89. Philip P. Frickey, (Native) American Exceptionalism in Federal Public Law, 119 HARV. L. REV. 431, 470-72 (2005). Frickey points to Justice Thomas's conclusion ("until we begin to analyze these questions honestly and rigorously, the confusion that I have identified will continue to haunt our cases," Lara, 541 U.S. at 226 (Thomas, J., concurring)) as an important invitation to renewed rigor and analysis of the doctrine of inherent tribal sovereignty. Frickey, supra, at 470-72.

90. See, e.g., Kyle S. Conway, Inberently or Exclusively Federal: Constitutional Preemption and the Relationship Between Public Law 280 and Federalism, 15 U. PA. J. CONST. L. 1323 (2013); Frickey, supra note 89; Robert Laurence, Don't Tbink of a Hippopotamus: An Essay on First-Year Contracts, Earthquake Prediction, Gun Control in Baghdad, the Indian Civil Rights Act, the Clean Water Act, and Justice Thomas's Separate Opinion in United States v. Lara, 40 TuLSA L. REV. 137 (2004); Ann E. Tweedy, Connecting the Dots Between the Constitution, the Marshall Trilogy, and United States v. Lara: Notes Toward a Blueprint for the Next Legislative Restoration of Tribal Sovereignty, 42 U. MICH. J.L. REFORM 651 (2009).

91. Lara, 541 U.S. at 227-31 (citing Oliphant v. Suquamish Tribe, 435 U.S. 191 (1978) and Duro v. Reina, 495 U.S. 676, 684, 688 (1990)).

92. Id. at 230.

93. Id. at 229 . 
With these challenges to the doctrine of inherent tribal sovereignty looming, the proper judicial role, if any, in assessing what remains of inherent tribal authority warrants closer examination. The next Part explores whether the courts ought to offer judicial review to litigants challenging inherent tribal authority under the theory of implicit divestiture, while at the same time effectively denying similar access to tribes, or whether those litigants are posing essentially political questions.

\section{INHERENT TRIBAL AUTHORITY AS A POLITICAL QUESTION}

This Part seeks to demonstrate that the inquiry into whether inherent tribal authority endures, or whether it has been implicitly divested, is not well suited for the judicial function; rather, it is a political question. Specifically, this Part applies the most significant factors enumerated by the Court in Bakerv. Carr ${ }^{94}$ to identify political questions to the questions courts seek to answer in determining whether inherent tribal authority has been implicitly divested. Evaluating these standards in the implicit divestiture context shows that when courts undertake the implicit divestiture inquiry, they may run afoul of the political question doctrine. Subpart IV.A applies each of the Baker v. Carr factors to the implicit divestiture inquiry: (i) judicial manageability of the standards, (ii) textual commitment to a coordinate branch, and (iii) policy determinations of a kind clearly of nonjudicial discretion. Subpart IV.B examines the effects and limitations of applying the political question doctrine in the area of law.

\section{A. The Bakerv. Carr Factors Applied}

In its discussion of the political question doctrine, Bakerv. Carr not only set forth categories of cases raising political questions, but it also identified a number of specific elements, the presence of any which one might suggest a nonjusticiable political question. ${ }^{95}$ In weighing whether a political question is present, the Baker factors are to be considered "in the disjunctive, not the conjunctive. To find a political question, we need only conclude that one factor is present, not all." 96 The following Subparts discuss each of the three most relevant Baker factors to the judicial consideration of whether inherent tribal authority endures or has been implicitly divested, and the tests courts have used to make such determinations. The Baker factors include: (i) the judicial manageability of standards; (ii) textual

94. Baker v. Carr, 369U.S. 186 (1962).

95. Id.

96. Schneider v. Kissinger, 412 F.3d 190, 194 (D.C. Cir. 2005). 
commitment to a coordinate branch; and (iii) policy determinations of a kind clearly for nonjudicial discretion. Each of these factors weighs in favor of the conclusion that courts should abandon the implicit divestiture inquiry and find such questions nonjusticiable.

\section{Judicial Manageability of Standards}

One of the prominent elements of a nonjusticiable political question is the "lack of judicially discoverable and manageable standards for resolving it." This element of the justiciability inquiry offers an especially useful tool for evaluating the standards courts have utilized to address questions about the scope of tribal sovereignty. ${ }^{98}$ As my previous work suggests, the standards courts have used in evaluating the scope of inherent tribal sovereignty do not fare well when measured against the indicators of judicial manageability. ${ }^{99}$

The mere fact that the courts have applied standards, even broad standards, rather than rules, does not make the standards infirm. ${ }^{100}$ But judicially discoverable and manageable standards ought to have at least three qualities: intelligibility, determinacy, and predictability. ${ }^{101}$ Though it seems perhaps obvious, Richard Fallon's examination of the jurisprudence of judicial manageability notes that for a "standard to count as judicially manageable, the most basic requirement is intelligibility, or 'capability of being understood." 102 Fallon cites as an example of an unintelligible standard one that requires the court to impute a specific legislative intent to a statute. ${ }^{103}$ There may be, and frequently is, broad disagreement about the intelligibility of particular standards. Fallon notes, for example, that while the

97. Id.

98. The Court has specifically held that questions related to the federal recognition of tribes, despite Congress's broad authority on the matter, are not per se political questions. See Baker, 369U.S. at 215.

99. Steele, supra note 18 , at $779,785-814$. Courts rely on a subjective categorization of some power as internal and others as external; however, courts have not articulated consistent, clear standards for which tribal powers are internal and which are external. For example, crimes committed against tribal members on tribal territory are categorized as an exercise of external power. Thus, tribes have been "circumscribed in the exercise of . . . the right to preserve public order through criminal jurisdiction under the Court's arbitrary internal-external relations paradigm." Id.

100. See Frank Cross et al., A Positive Political Theory of Rules and Standards, 2012 U. ILL. L. REV. 1, 16 (2012) (stating that the "key difference between rules and standards is the 'relative discretion they afford to the decisionmaker." (quoting Kathleen M. Sullivan, Foreword: The Justices of Rules and Standards, 106 HARV. L. REV. 22, 57 (1992))).

101. Richard H. Fallon, Jr., Judicially Manageable Standards and Constitutional Meaning, 119 HARV. L. REV. 1275, 1285-95 (2006).

102. Id. at 1285 (quoting WEBSTER's NEW TWENTIETH CENTURY DICTIONARY OF THE ENGLISH LANGUAGE 954 (2d ed. unabr. 1979).

103. Id. at 1285-86 (observing that a "multimember body ... has no unitary intent" and that the search for an intent is considered by some to be unintelligible). 
majority of the Supreme Court finds the standard weighing state and national interests to assess burdens on commerce under the dormant Commerce Clause to be intelligible, Justice Scalia disagrees, reasoning that " $[\mathrm{t}]$ he scale analogy is not really appropriate, since the interests on both sides are incommensurate. It is more like judging whether a particular line is longer than a particular rock is heavy." 104

A judicially manageable standard should also be determinate. ${ }^{105}$ Determinacy measures a standard's consistency and effectiveness in avoiding arbitrary results and line drawing. ${ }^{106}$ According to Fallon, this means avoiding standards "for which conceptual resources are lacking in too many instances."107 He illustrates the point with the application of the standard assessing activities with "direct effects" and "indirect effects" on commerce. ${ }^{108} \mathrm{He}$ writes:

The problem was not that the criteria for sorting direct from indirect effects were difficult to apply, for criteria can be difficult to apply but still have plenty of resolving power in the hands of those who know how to deploy them competently. Rather, the problem was that there were no criteria sufficient to make nonarbitary distinctions between direct and indirect effects, no matter how smart and knowledgeable the analyst might be. ${ }^{109}$

For a standard to offer sufficient determinacy, then, it must offer discernible, consistent criteria that do not lead to arbitrary results.

The third criterion for a judicially manageable standard is predictability. ${ }^{110}$ Where lower courts apply a standard "unpredictably or inconsistently, the standard is likely to be deemed judicially unmanageable." Where there seems to be no general consensus about "the meaning of underlying norms," or where the judgments of lower courts may be vulnerable to political influence, a standard can lead to unpredictable and inconsistent results, and thereby is regarded as judicially unmanageable. ${ }^{112}$

With these three criteria in mind, I examine three specific standards employed by courts in assessing assertions of inherent tribal authority. When courts

104. Id. at 1286 (quoting Bendix Autolite Corp. v. Midwesco Enters., Inc., 486 U.S. 888, 897 (1988)

(Scalia, J., concurring in judgment)).

105. Id. at 1287 .

106. Id.

107. Fallon, Jr., supra note 101, at 1287.

108. Id.

109. Id.

110. Id. at 1289-90.

111. Id. at 1290.

112. Id. 
have undertaken to evaluate whether a tribe's inherent authority endures, they have generally turned to some combination of three standards: (a) an external-power/internal-relations standard; (b) a necessary-to-protect-tribal-selfgovernment standard; and (c) an inconsistent-with-dependent-status standard. ${ }^{113}$ Courts sometimes conflate these standards, as these certainly overlap. Indeed, the closer examination of the application of these standards which follows calls into question their judicial manageability.

\section{a. External Relations and Internal Power}

In seeking to address whether a tribe retains inherent sovereign authority in a particular area, courts have sometimes looked at whether the assertion of sovereignty involves an external or an internal sovereign power. ${ }^{114}$ If they find the power to involve the "external relations" of the tribe as sovereign, courts have deemed the power to be "inconsistent with [tribes'] dependent status." 115 As a result, tribes may be precluded from exercising regulatory or adjudicatory authority over people and territory even within the boundaries of the reservation. On the other hand, where the power asserted is deemed "internal," courts find that "an Indian tribe generally retains sovereignty by way of tribal self-government and control over other aspects of its internal affairs."116

Frickey finds the origin of this standard in Chief Justice Marshall's conception of tribal sovereignty, including: "[G]eneral presumptions that, prior to discovery, tribes possessed complete, inherent sovereignty; that discovery had reduced their sovereignty only with respect to external sovereign relations; and that in the treaty-making process neither Great Britain nor the United States had sought to interfere with internal tribal governance."117

113. See, e.g., Montana v. United States, 450 U.S. 544, 564 (1981); see also Steele, supra note 18, at 792-94.

114. See Alex Tallchief Skibine, Tribal Sovereign Interests Beyond the Reservation Borders, 12 LEWIS \& CLARK L. REV. 1003, 1010 (2008) (stating that recently the Court has "redefin[ed] the concept and powers of tribal self-government as being limited to governance of internal relations or purely intramural matters").

115. Montana, 450 U.S. at 564 (emphasis omitted).

116. Brendale v. Confederated Tribes \& Bands of Yakima Indian Nation, 492 U.S. 408, 425 (1989); see also Montana, 450 U.S. at 564; United States v. Wheeler, 435 U.S. 313, 322 n.18 (1978) (shedding some light on the Court's conception of the internal powers of tribes: determining tribal membership, regulating domestic relations among tribal members, and prescribing rules for the inheritance of property). But see Vann v. Kempthorne, 534 F.3d 741 (D.C. Cir. 2008); Vann v. Kempthorne, 467 F. Supp. 2d 56 (D.C. Cir. 2006); Cherokee Nation v. Nash, 724 F. Supp. 2d 1159 (N.D. Okla. 2010) (challenging the power of the Cherokee Nation to limit voting rights on the basis of race).

117. Frickey, Marshalling, supra, note 35, at 399. 
Under this external-relations/internal-powers standard, the tribes were in some ways on equal footing with states. As with tribes, states lack powers of external, or foreign, relations and are circumscribed by the superior sovereignty of the United States in their ability to conduct commercial and diplomatic relations with foreign powers; however states, like tribes, retain the powers of local governance, or internal sovereignty. ${ }^{118}$ Tribes cannot form alliances with foreign nations or bargain for the transfer of tribal lands with individuals or sovereigns, except with the United States. ${ }^{119}$ It is unremarkable that the subordinate sovereign cannot undermine the national interests or foreign relations of the superior, dominant sovereign. The conduct of foreign relations is an "external relations power" of the United States and exclusively so for all under its authority. ${ }^{120}$

In Brendale v. Confederated Tribes and Bands of Yakima Indian Nation, which evaluated inherent tribal authority in the context of zoning within reservation boundaries, the Court cited examples of external powers that had been implicitly divested from tribes: the right to freely alienate lands to non-Indians; commercial and governmental relations with foreign nations; and criminal jurisdiction over non-Indians in tribal courts. ${ }^{121}$ However, as Brendale makes clear, the standard in its modern application has morphed far beyond Brendale's own limited initial conception of what constitutes the external relations of a tribe. ${ }^{122}$ Indeed, the expanding evolution and malleability of the standard's application raise legitimate questions as to whether the standard is judicially manageable; in particular,

118. See Stefan A. Riesenfeld, The Power of Congress and the President in International Relations: Three Recent Supreme Court Decisions, 87 CALIF. L. REV. 786, 809 n.109 (1999) ("I entertain this general idea, that the states retained all internal sovereignty, and that congress properly possessed the rights of external sovereignty." (quoting 1 STORY, COMMENTARIES ON THE CONSTITUTION OF THE. UNITED STATES $\$ 216(1833))$ ).

119. The Non-Intercourse Act codifies the principle of exclusive federal-tribal dealings, though not by constraining tribes, per se, but by making land transactions with tribes illegal. See 25 U.S.C. $\S$ 177 (2012).

120. Indeed, while the external relations power may be predominantly the province of the Executive, it is significant that questions concerning the external relations power are generally held to be nonjusticiable. See William Bradford, "With a Very Great Blame on Our Hearts": Reparations, Reconciliation, and an American Indian Plea for Peace With Justice, 27 AM. INDIAN L. REV. 1, 90 (2002-2003) (noting that "courts scrupulously abstain from, and dismiss, foreign relations cases").

121. 492 U.S. 408, 426 (1989) (saying that the "list is by no means exclusive" and citing Oneida Indian Nation v. County of Oneida, 414 U.S. 661, 667-68 (1974); Worcester v. Georgia, 31 U.S. (6 Pet.) 515, 559 (1832); Oliphant v. Suquamish Tribe, 435 U.S. 191, 195 (1978); and Montana v. United States, 450 U.S. 544, $564(1981))$.

122. Whereas the Brendale Court initially acknowledged that external relations involved such things as foreign relations and commerce by a tribe, arguably more clearly within the category of external, the Court applied the standard to find that tribe regulating land use within its own reservation boundaries was somehow also an exercise of extinguished external power. Brendale, 492 U.S. at 428. 
though on its face the standard is intelligible, a review of cases reveals a lack of determinacy and predictability in the application of the standard.

The Court in Brendale examined the efforts of the Yakima Nation to establish a zoning code within the reservation boundaries. ${ }^{123}$ The Tribe enacted a zoning code in an effort to regulate development within the reservation boundaries; this legislation affected a significant number of non-Indians living within the reservation boundaries. The non-Indian residents of the reservation, primarily living on fee lands, challenged the authority of the Tribe to regulate their activities through land use ordinances. The Court relied on the external-relations/internalpowers test to hold that the Yakima Nation could not regulate the land use activities of most nonmembers of the tribe within the reservation boundaries because the power asserted to zone involves "relations between an Indian tribe and nonmembers of the tribe." 124 The Court found that regulation of the land use activities of non-Indians within the reservation was an exercise of "external relations." 125 As a result, the Court found the inherent tribal authority to zone to have been divested. ${ }^{126}$

Similarly, in Montana v. United States, the Court considered the Crow Tribe's assertion that it had the inherent tribal authority to regulate hunting and fishing activities within the boundaries of the reservation. ${ }^{127}$ Because the regulations would apply to the activities of non-Indians on fee lands within the reservation, the Court considered whether the tribal regulations asserted an external relations power or sought to govern internal relations. ${ }^{128}$ The Court relied on the reasoning of Oliphant v. Suquamish Indian Tribe, ${ }^{129}$ finding that tribes, having only internal rather than external powers, had been divested of inherent tribal authority to criminally prosecute non-Indians. In Montana, the Court found the reasoning of Oliphant under this standard to support a much broader "general proposition that the inherent sovereign powers of an Indian tribe do not extend to the activities of nonmembers of the tribe." 130

But is this broad general proposition compelled by the externalrelations/internal-power inquiry? It is worth asking what is inherently external

123. $I d$.

124. Id. But see the exceptions in Montana v. United States, 450 U.S. 544, 565 (1981).

125. Brendale, 492 U.S. at 428 ("[U]nder the general principle enunciated in Montana, the Yakima Nation has no authority to impose its zoning ordinance on the fee lands owned by petitioners ....").

126. The Court did conduct a further analysis under the two Montana exceptions, discussed below, but found the exceptions not to be satisfied to overcome the external relations divestiture. $I d$.

127. 450 U.S. 544 (1981).

128. Id. at 564 .

129. Oliphant v. Suquamish Tribe, 435 U.S. 191, 209-10 (1978).

130. Montana, 450 U.S. at 565. 
about the activities of nonmembers on the reservation, especially when those activities may include assault upon the tribe's people or despoliation of tribal resources. ${ }^{131}$ Rather than engage in this difficult and indeterminate analysis, the Court modified the general proposition of tribal impotence over the activities of non-Indians in the very next sentence of Montana, indicating some exceptions:

To be sure, Indian tribes retain inherent sovereign power to exercise some forms of civil jurisdiction over non-Indians on their reservations, even on non-Indian fee lands. A tribe may regulate, through taxation, licensing, or other means, the activities of nonmembers who enter consensual relationships with the tribe or its members, through commercial dealing, contracts, leases, or other arrangements. . . A tribe may also retain inherent power to exercise civil authority over the conduct of non-Indians on fee lands within its reservation when that conduct threatens or has some direct effect on the political integrity, the economic security, or the health or welfare of the tribe. ${ }^{132}$

Applications of the standard, including the Montana exceptions, raise questions of determinacy and predictability. On the one hand, under the external-relations/internal-powers standard as applied in Montana, tribes are generally divested of sovereign authority over the activities of nonmembers as these are generally within the ambit of external relations. Tribal regulation of nonmember hunting and fishing and tribal zoning of land use activities by nonmembers on fee lands within the reservation were found in Montana and Brendale to involve external relations. On the other hand, some activities of nonmembers of the tribe may sufficiently impact the tribal interest in governing internal relations so as to convert the power asserted by the tribe from an external to an internal power.

Nevertheless, a review of cases applying the standard and formulation of Montana and its exceptions shows that tribes, other litigants, and lower courts have all found this standard difficult. For example, applying the same standard, the line drawing over tribal taxing authority - as a function on inherent tribal authority - seems somewhat arbitrary. In Merrion v. Jicarilla Apache Tribe, the Court upheld a tribal severance tax on non-Indians extracting oil and gas within

131. It is difficult to reconcile this broad apparent divestiture of inherent authority over people and territory under the auspices of "external relations," with the assurance in United States v. Mazurie that tribes are "unique aggregations possessing attributes of sovereignty over both their members and their territory ... [and] are a good deal more than "private, voluntary organizations." 419 U.S. 544, 557 (1975) (upholding Tribe's regulation, pursuant to a delegated federal authority, of introduction of intoxicants into the reservation, even on non-Indian land).

132. Montana, 450 U.S. at 565-66. 
the reservation as an exercise of inherent tribal authority. ${ }^{133}$ Yet in Atkinson Trading Co. v. Shirley, the Court struck down a tribal hotel occupancy tax on nonIndians staying in a hotel on a reservation that made use of tribal public services, finding the tax to fall under the general proposition in Montana that tribes are generally divested of power over the activities of nonmembers. ${ }^{134}$ Such line drawing is arguably not predictable and results in costly litigation for tribes and others.

The legacy of the external-relations/internal-powers standard is confusion and ultimately it should not be employed by courts to determine inherent tribal authority. ${ }^{135}$

\section{b. Necessary to Protect Self-Government}

After Montana, one of the inquiries courts have made in assessing the endurance of inherent tribal authority is whether the power asserted is "necessary to protect tribal self-government." 136 A year later in Merrion, the Court held that "the Tribe's authority to tax non-Indians who conduct business on the reservation . . . is an inherent power necessary to tribal self-government and territorial management." 137 But the divergent outcomes in Merrion and Atkinson beg the question of how objective, judicially manageable standards put some forms of taxation of nonmember activities on the reservation on one side of the "necessary powers" line, and keep other assertions of tribal self-government and territorial management outside that designation.

133. 455 U.S. $130,141-43(1982)$

134. 532 U.S. $645,652-54$ (2001). The Ninth Circuit has also attempted to apply the standard with variable results. See Morongo Band of Mission Indians v. Rose, 893 F.2d 1074 (9th Cir. 1990); Chilkat Indian Village v. Johnson, 870 F.2d 1469 (9th Cir. 1989). The Ninth Circuit also wrestled with the applicability of the external-relations/internal-powers standard in considering an assertion of sovereign immunity by the Yakima Nation. In re Greene, 980 F.2d 590, 596 (1992), superseded by statute, 11 U.S.C.A. $\$ 106$ (West 2015), as recognized in In re Russell, 293 B.R. 34 (Bankr. D. Ariz. 2003). The court concluded that the standard was inapplicable because a claim of tribal sovereign immunity does involve "external relations" but is legally distinct from an affirmative assertion of tribal sovereignty. Id.

135. See John Fredericks III, America's First Nations: The Origins, History and Future of American Indian Sovereignty, 7 J.L. \& POL'Y 347, 401 (1999) (stating that the Supreme Court's "ad hoc approach" to tribal sovereignty has "been the creation of a body of law that has become extremely unpredictable"); David H. Getches, Conquering the Cultural Frontier: The New Subjectivism of the Supreme Court in Indian Law, 84 CALIF. L. REV. 1573, 1576 (1996) (calling the Supreme Court's approach to Indian sovereignty a "rudderless exercise in judicial subjectivism").

136. Montana v. United States, 450 U.S. 544, 564 (1981) (“[E]xercise of tribal power beyond what is necessary to protect tribal self-government or to control internal relations is inconsistent with the dependent status of the tribes, and so cannot survive without express congressional delegation." (citing Mescalero Apache Tribe v. Jones, 411 U.S. 145, 148 (1973))).

137. Merrion v. Jicarilla Apache Tribe, 455 U.S. 130, 141 (1982). But see Atkinson Trading Co., 532 U.S. 645, 652-54 (2001); supra note 134 and accompanying text. 
In Strate v. A-1 Contractors, the Court considered whether the tribal court of the Three Affiliated Tribes of the Fort Berthold Reservation could assert civil jurisdiction over an accident arising on trust land involving a non-Indian plaintiff from the community. ${ }^{138}$ The plaintiff, Gisele Fredericks, a non-Indian, had been married to a tribal member, and her children were members of the tribe. ${ }^{139}$ After an accident on a section of state highway running through the reservation pursuant to a right-of-way, Ms. Fredericks sued the non-Indian defendant in tribal court. ${ }^{140}$

The Court weighed the Tribe's interest in adjudicating the dispute against the standard of whether the tribal court jurisdiction was necessary to protect tribal self-government and found that Fredericks' use of the tribal court was "not necessary to protect tribal self-government" under Montana and its exceptions. ${ }^{141}$ The Court reasoned that the plaintiff had recourse to the state court for her claim and that, since both parties to the dispute were non-Indians, the tribal adjudicatory interest was minimal. ${ }^{142}$ The Court dismissed concerns about the plaintiffs ties to the tribal community and the trust status of the land underlying the highway to apply the Montana rule against tribal jurisdiction: "Opening the Tribal Court for [the plaintiffs] optional use is not necessary to protect tribal self-government; and requiring $\mathrm{A}-1 \ldots$ to defend against this commonplace state highway accident in an unfamiliar court is not crucial to 'the political integrity, the economic security or the health or welfare of the [Tribes]."'143

Following Strate, a federal district court read the Montana and Strate concept - that is, preserving only those tribal powers necessary to protect tribal self-government-as creating a presumption against tribal authority over nonmembers unless Congress has clearly stated otherwise. ${ }^{144}$ In its evaluation of a tax on a telecommunication company's activities on the reservation, the court found that in order for tribal authority to be sustained, the nonmember conduct must "threaten[] the Indian tribe" and "does not permit the exercise of [tribal] civil authority when it may arguably be considered 'necessary' to selfgovernment." 145

A federal district court in Mississippi wrestled with the necessary-to protect-tribal-self-government standard in determining whether the tribal court

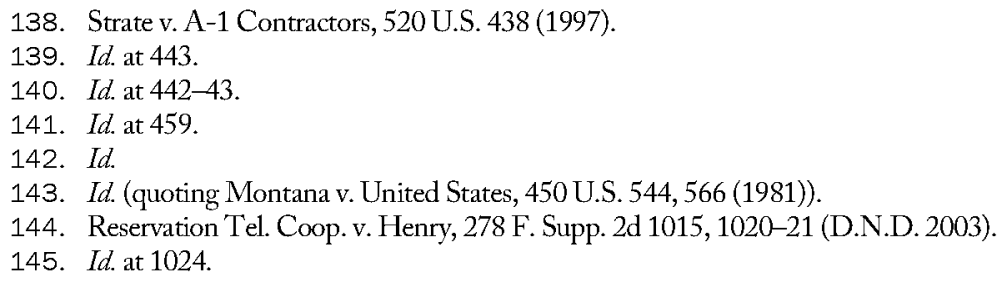


could exercise jurisdiction over a dispute between non-Indians arising in a store located on trust land belonging to the Mississippi Band of Choctaw Indians. ${ }^{146}$ The district court upheld jurisdiction because it found the store owners, Dollar General, constructively consented to jurisdiction as a participant in a tribalsponsored youth program. ${ }^{147}$ In so holding, the court muddled the standard "necessary to tribal self-government." The court read the standard to erect a high and confusing hurdle indeed for tribal jurisdiction under the second Montana exception:

[T] ribal jurisdiction over the ... claims cannot be sustained under the second Montana exception, not because tribal jurisdiction is not necessary to protect tribal self-government or control internal relations, but rather because the nonmember conduct at issue does not "imperil the subsistence' of the tribal community" and ... thus cannot be necessary to avert catastrophic consequences. ${ }^{148}$

The court's analysis is confusing, to say the least. The import of the district court's holding is that tribal jurisdiction may be necessary to protect selfgovernment and to control internal relations but may still fail because it is not "necessary to avert catastrophic consequences" for the tribe. ${ }^{149}$

The Fifth Circuit affirmed the exercise of tribal court jurisdiction over the dispute, finding that "[d] espite the limitations recognized in Montana and subsequent cases, the Court has consistently acknowledged that ' $[t]$ ribal authority over the activities of non-Indians on reservations lands is an important part of tribal sovereignty."'150 The Circuit Court did not address whether the exercise of tribal court jurisdiction was necessary to protect tribal self-government. ${ }^{151}$ The Supreme Court will shortly address the question of whether tribal court jurisdiction was appropriate in this case and may provide additional guidance about whether and how the necessary-to-protect-tribal-self-government test applies in that inquiry. ${ }^{152}$

146. See Dolgencorp Inc. v. Miss. Band of Choctaw Indians, 846 F. Supp. 2d 646, 649-50 (S.D. Miss. 2011).

147. Id. at 650 .

148. Id.

149. Id.

150. Dolgencorp, Inc. v. Miss. Band of Choctaw Indians, 746 F.3d 167, 172 (5th Cir. 2014) (citing Iowa Mut. Ins. Co. v. LaPlante, 480 U.S. 9, 18 (1987)).

151. Id. at 177-78 (Smith, J. dissenting) (arguing that "[f]or the first time ever a federal court of appeals upholds Indian tribal-court jurisdiction over a non-Indian, based on a consensual relationship, without a finding that jurisdiction is 'necessary to protect tribal self-government or control internal relations.").

152. Dollar Gen. Corp. v. Miss. Band of Choctaw Indians, 135 S. Ct. 2833 (2015). 


\section{c. Inconsistent with Dependent Status}

As discussed above, in 1978, the Court introduced in Oliphant a new standard for evaluating an assertion of inherent tribal authority when it debuted the idea of implicit divestiture. ${ }^{153}$ Before Oliphant, tribes were generally believed to have inherent authority over internal affairs, including people and territory, except to the extent that it had been expressly divested either by treaty or by statute. Finding no express limitation by Congress, or by treaty, as to the Suquamish Tribe's power to prosecute non-Indians for assaults on tribal officers and property, Oliphant found that this power had been impliedly divested from tribes because such criminal jurisdiction is "inconsistent with their status" as tribes. ${ }^{154}$ At the time of Oliphant, 33 of the 127 tribal judiciaries exercised criminal jurisdiction over the acts of non-Indians on the reservation. ${ }^{155}$ The Ninth Circuit's assessment of the Tribe's criminal jurisdiction reasoned that "criminal jurisdiction over anyone committing an offense on the reservation" to be the "sine qua non" of tribal sovereignty. ${ }^{156}$ But the Supreme Court disagreed:

Indians do not have criminal jurisdiction over non-Indians absent affirmative delegation of such power by Congress. Indian tribes do retain elements of "quasi-sovereign" authority after ceding their lands to the United States and announcing their dependence on the Federal Government. But the tribes' retained powers are not such that they are limited only by specific restrictions in treaties or congressional enactments... [T] ribes are prohibited from exercising both those powers of autonomous states that are expressly terminated by Congress and those powers "inconsistent with their status."157

In the aftermath of Oliphant, some courts have assessed assertions of inherent tribal authority, in part, for whether or not the tribal power is consistent with the "dependent status" of tribes. ${ }^{158}$ Most often, the courts find that the dependent status of tribes, whatever that might mean, must result in the inference that the tribal authority has been divested by implication, even though Congress has not addressed the issue.

Indeed, courts have faithfully recited the standard announced in Oliphant, and extended in Montana and Strate, and have proceeded to seek more

\footnotetext{
153. 435 U.S. 191, 203-04 (1978).

154. Id. at 208.

155. Id. at 196.

156. Id. (emphasis added).

157. Id. at 208 (citation omitted).

158. Montana v. United States, 450 U.S. 544, 563 (1981); Dolgencorp Inc. v. Miss. Band of Choctaw Indians, 846 F. Supp. 2d 646, 649 (S.D. Miss. 2011).
} 
manageable standards that are hinted at, but not made clear, in the precedent. Courts have sought to synthesize rules by inquiring whether the challenged tribal power is adjudicatory or legislative, and whether the tribe seeks to exercise jurisdiction over tribal members or nonmembers. ${ }^{159}$ The precedent suggests that these are relevant but not conclusive inquiries. The struggle of the courts to apply these standards has led to indeterminate and inconsistent results.

Although Montana provided that tribes retain inherent authority over nonmembers with consensual or commercial relationships with the tribe, the Ninth Circuit recently extended Montana and Strate even further. In Phillip Morris USA, Inc. v. King Mountain Tobacco Co., the court held that the Yakama tribal court did not have inherent jurisdiction over a nonmember unless "the claim has a nexus to the consensual relationship between the nonmember and the disputed commercial contacts with the tribe." ${ }^{60}$ Presumably, the court found the exercise of tribal inherent authority in this context to be inconsistent with the dependent status of the tribe, and therefore the tribal court had been divested of such jurisdiction, even though Congress had not spoken to this issue. ${ }^{161}$ The court documented the difficulty of the task of determining the scope of inherent civil adjudicatory jurisdiction, observing that " $[\mathrm{t}]$ ribal jurisdiction cases are not easily encapsulated, nor do they lend themselves to simplified analysis." ${ }^{162}$ Rather than identifying clear standards, the court looked to the precedent cases and found instead "guiding principles," including consistency with the dependent status of tribes. ${ }^{163}$ The court characterized the "ground rules governing tribal adjudicatory jurisdiction over nonmembers" as a general rule that "tribes do not have jurisdiction, either legislative or adjudicative, over non-members, and tribal courts are not courts of general jurisdiction." 164

In Dolgencorp, Inc. v. Mississippi Band of Choctaw Indians, the Fifth Circuit evaluated a similar question involving the exercise of inherent tribal authority over a claim involving a nonmember who challenged tribal court jurisdiction. ${ }^{165}$ The court characterized tribes as "independent sovereign communities that have lost some aspects of sovereignty." ${ }^{166}$ In contrast to King Mountain, however, the court found that the tribal court did indeed have the inherent tribal authority to

\footnotetext{
159. See, e.g., Strate v. A-1 Contractors, 520 U.S. 438, 452-53 (1997).

160. 552 F.3d. 1098, 1108 (9th Cir. 2009).

161. This extension of the Montana-Strate rule was effectuated without the tribe being party to the case. Id.

162. Id. at 1102 (noting that the Supreme Court has called such questions a "complex patchwork of federal, state, and tribal law" (quoting Duro v. Reina, 495 U.S. 676, 680 n.1 (1990))).

163. Id

164. Id. at $1104-05$.

165. 746 F.3d 167 (5th Cir. 2014).

166. Id. at 171 .
} 
hear a civil claim against a nonmember and his employer. Even though the claim did not specifically arise from the employer's commercial activities on the reservation, the court found a sufficient nexus to permit the tribal court's jurisdiction.

The way the courts in King Mountain and Dolgencorp characterized the nature of tribes and of tribal sovereignty may not have been determinative to the divergent outcomes here, but they offer an interesting window into the judicial thinking about what inherent powers are consistent or inconsistent with such sovereignty. Ultimately, the standards that have emerged to guide the inquiry into whether inherent tribal authority endures or whether it has been implicitly divested have confounded courts and litigants. They do not fail the test of judicial manageability merely because they are difficult to apply, though they are; rather, these standards fail to meet the benchmarks of judicial manageability in that they are neither intelligible, determinate, nor predictable. The struggle of the courts to apply the standards consistently reveals line drawing that is not particularly arbitrary, but not particularly just either, for it seems most frequently to come at the cost of tribal authority.

\section{Textual Commitment to Coordinate Branch}

The essence of the political question doctrine is a court's concern that by addressing a political question, it is violating the separation of powers doctrine. ${ }^{167}$ Our tripartite system divides the powers of governance into three distinct branches; under the separation of powers doctrine, the coordinate branches may not invade the province of another branch. The purview of the legislative branch is deliberative policymaking through the enactment of law. ${ }^{168}$ The implicit divestiture inquiry not only relies on unmanageable standards, but it also treads upon the role of Congress in managing tribal relations and setting federal Indian policy.

As discussed above in Part II.A, the federal plenary power over Indian affairs resides primarily with Congress. The textual source of that plenary power is frequently traced to the Indian Commerce Clause and to the power of the Senate

167. See Baker v. Carr, 369 U.S. 186, 210 (1962).

168. In the early twentieth century, Oregon enacted legislative initiative and referendum provisions that were challenged as violating Article IV of the Constitution's guarantee of a "republican form of government." See Pac. States Tel. \& Tel. Co. v. Oregon, 223 U.S. 118, 137-42 (1912). The suit sought to enforce the Guarantee Clause in the courts. The Court declined to take jurisdiction over the suit as presenting "a matter purely political for the judgment of Congress on a subject committed to it." Id. Despite concerns about the reasoning of the case, "the Supreme Court has never questioned the holding of nonjusticiability in Pacific States." Kerr v. Hickenlooper, 759 F.3d 1186, 1188 (10th Cir. 2014) (Hartz, J., dissenting). 
to ratify treaties negotiated by the Executive. Congress has specifically delegated some powers over Indian affairs to the Executive branch through the President and the Secretary of Interior. But neither the Constitution nor any jurisdictional statute imbue the judiciary with any particular role in setting federal Indian policy or managing federal-tribal relations.

The inquiry into "whether and to what extent the issue is textually committed" does frequently require the judiciary to look to and interpret relevant constitutional text. ${ }^{169}$ But in determining justiciability, the courts are guided by the principle that a "controversy is nonjusticiable-i.e., involves a political questionwhere there is 'a textually demonstrable constitutional commitment of the issue to a coordinate political department."'170 In Nixon v. United States, an impeached federal judge sought judicial review of the Senate's rules and procedures governing impeachment as violating the Constitution's Article I impeachment clause. ${ }^{171}$ The Court found the question to be nonjusticiable in large part because Article I had committed the impeachment power, including "the sole Power to try all Impeachments" to the Senate. ${ }^{172}$ In undertaking the inquiry, the Court noted that "the concept of a textual commitment to a coordinate political department is not completely separate from the concept of a lack of judicially discoverable and manageable standards for resolving it; the lack of judicially manageable standards may strengthen the conclusion that there is a textually demonstrable commitment to a coordinate branch." ${ }^{173}$

As in Nixon, there is relevant text in the Constitution's Article I that bears upon the power to resolve issues of inherent tribal sovereignty, by committin the Indian commerce power to a coordinate branch. The Commerce Clause provides that "Congress shall have Power ... To regulate Commerce with foreign Nations, and among the several States, and with the Indian Tribes." 174 The fact that this broad regulatory power is textually committed to Congress is significant here. The text also demonstrates that the Constitution classifies and regards Indian tribes as sovereign entities comparable to, and yet distinguishable from, foreign nations and states. In addition, the text suggests that Congress's power in regulating commerce with the Indian nations is akin to its power to regulate commerce with foreign nations, or, in other words, the power to conduct bilateral, nation-to-nation political relations.

169. Nixon v. United States, 506 U.S. 224, 228 (1993).

170. Id. (quoting Baker, 369 U.S. at 217).

171. Id.

172. U.S. CONST. art. I, $\S 3$, cl. 6

173. Nixon, 506 U.S. at $228-29$.

174. U.S. CONST. art. I, $\S 8$, cl. 3 . 
The conduct of foreign relations has always been an area of suspect justiciability. ${ }^{175}$ As United States v. Curtiss-Wright Export Corp. holds, the political branches are the instruments of nationality, possessing all the "plenary" powers inherent to sovereignty flowing therefrom: "[T] he United States is invested with all the attributes of sovereignty. As it has the character of nationality it has the powers of nationality, especially those which concern its relations and intercourse with other countries. We should hesitate long before limiting or embarrassing such powers." ${ }^{\prime 76}$ The conduct of Indian affairs by the political branches, rather than by the judiciary is analogous here: The Indian affairs power is rooted in constitutional text that suggests the power is a concomitant of nationality in the same sense that the conduct of foreign affairs is an essentially political rather than judicial function. ${ }^{177}$ The Treaty Clause and treaty power, while not mentioning Indian tribes per se, reinforce this analogy of Indian affairs to foreign relations. ${ }^{178}$

The construction and history of the Indian Commerce Clause is also distinguishable from the construction and history of the Interstate Commerce Clause. While the Interstate Commerce Clause serves as a check on the federal government's power vis-à-vis the states as an enumerated power, the nexus to commerce required by the Interstate Commerce Clause has not been similarly incorporated into the construction of the Indian Commerce Clause. ${ }^{179}$ Describing these fundamentally distinct commerce clauses, the Court noted in Cotton Petroleum Corp. v. New Mexico the "well established" doctrine "that the Interstate Commerce and Indian Commerce Clauses have very different applications." Court identified the central functions of these clauses as serving very different purposes: "the Interstate Commerce Clause is concerned with maintaining free trade among the States ... [while] the central function of the Indian Commerce Clause is to provide Congress with plenary power to legislate in the field of Indi-

175. See, e.g., Oetjen v. Cent. Leather Co., 246 U.S. 297, 302-03 (1918) (holding that the political question doctrine has particular application in the foreign relations context); Schneider v. Kissinger, 412 F.3d 190, 193 (D.C. Cir. 2005) (noting that in United States v. Palmer, Chief Justice Marshall "described questions of foreign policy as belong[ing] more properly to those ... who can place the nation in such a position with respect to foreign powers as to their own judgment shall appear wise; to whom are entrusted all its foreign relations; then to that tribunal whose power as well as duty is confined to the application of the rule which the legislature may prescribe for it." (quoting 16 U.S. (3 Wheat.) 610, $634(1818))$ ).

176. 299 U.S. 304, 322 (1936) (quoting Mackenzie v. Hare, 239 U.S. 299, 311 (1915)).

177. See United States v. Lara, 541 U.S. 193, 201 (2004); see also Curtiss-Wright, 299 U.S. at 322.

178. U.S. CONST. art 2, § 2, cl. 2; see also Morton v. Mancari, 417 U.S. 535, 552 (1974) (observing that the treaty power "has often been the source of the Government's power to deal with the Indian tribes").

179. See Cotton Petroleum Corp. v. New Mexico, 490 U.S. 163, 192 (1989).

180. Id. 
an affairs." ${ }^{181}$ Because the Interstate Commerce Clause involves the structural relationships of constitutional federalism, it is distinguishable from the Indian Commerce Clause. ${ }^{182}$ As a result, the Court does not "readily import[]" the principles and construction of the Interstate Commerce Clause into "cases involving the Indian Commerce Clause." 183

In sum, the textual commitment of the Indian Commerce Clause is much broader than the powers enumerated by and contained within the Interstate Commerce Clause, according to the Court's own reading of the text. By this rationale, as the Court has recognized the Indian Commerce Clause as providing a plenary legislative power, the Court ought to be wary of exercising judicial authority over questions of tribal authority, which are at the heart of Congress's relationship with, and regulation of, tribes.

\section{Initial Policy Determinations of a Kind Clearly for Non-Judicial Discretion}

In developing and applying the implicit divestiture doctrine, courts have undertaken what amounts to federal Indian policy determinations under the guise of judicial decision making. As with the lack of judicially manageable standards and the textual commitment to coordinate branch considerations, the judiciary's implicit divestiture tests require initial policy determinations of a kind that is clearly for nonjudicial discretion and therefore suggest a political question.

Specifically, the nature and scope of federal-tribal relations and the powers of tribes recognized by the federal government are policy questions within the competence of Congress's Indian affairs power. The implicit divestiture inquiry invades this province by making initial policy judgments, rather than legal judgments, about what inherent sovereign powers do or ought to remain to tribes, without the benefit of congressional input. In other words, Congress is capable of recognizing and affirming inherent tribal powers and has done so on numerous occasions. Congress is also capable of extinguishing tribal powers under the plenary power doctrine, and has done so on numerous occasions. Under the implicit divestiture inquiry, the courts exploit congressional silence to formulate an initial policy determination reordering the federal-tribal relationship and potentially frustrating policy choices made by the political branches. ${ }^{184}$

181. Id. (citing Morton, 417 U.S. at 551-52).

182. See id.

183. Id

184. The legal literature is replete with examples of the view that the modern Supreme Court has intruded into the policymaking function of Congress in the realm of Indian affairs, primarily 
There have been cases challenged as presenting political questions requiring policy determinations and that have been nonetheless found to be justiciable. For example, in Japan Whaling Ass'n v. American Cetacean Society, the Japanese whalers argued that the judicial branch could not order the executive branch to certify that Japan was in violation of an international whaling treaty because the question was essentially a political question concerning the conduct of foreign affairs. ${ }^{185}$ The Court explained,

The political question doctrine excludes from judicial review those controversies which revolve around policy choices and value determinations constitutionally committed ... to the halls of Congress or the confines of the Executive Branch. The Judiciary is particularly ill suited to make such decisions, as "courts are fundamentally underequipped to formulate national policies or develop standards for matters not legal in nature." 186

However, in the whaling case, the Court characterized the question as fundamentally legal because it required nothing more than traditional statutory interpretation, well within the competence of the judiciary. ${ }^{187}$

By contrast, the question of whether inherent tribal sovereign powers have been "implicitly divested" is not a question of statutory interpretation, but is, on its face, a policy determination made by the judiciary in the absence of congressional action. As such, the implicit divestiture inquiry appears to address a controversy that revolves around policy choices committed to the halls of Congress rather than to judicial determination. The D.C. Circuit, for example, declined to entertain a question that would have required the court "to pass judgment on the policy-based decision of the executive to use covert action" in a foreign intelligence operation. ${ }^{188}$ The court found that " $[t]$ o determine whether drastic

following the announcement of the implicit divestiture doctrine. The phenomenon has been well documented and loudly protested. See, e.g., Deloria \& Newton, supra note 8, at 72 ("[T] has begun to impose its own notions of the role of tribal governments in the United States system, arrogating to itself an authority committed by the Constitution to Congress."); Frickey, supra note 10, at 8 ("[The Supreme Court] has been displacing the primary congressional responsibility for Indian affairs with a judicial attempt to address contemporary contextual dilemmas in federal Indian law on a case-by-case basis."); Recent Legislation, Indian Law-Tribal Courts-Congress Recognizes and Affirms Tribal Courts' Special Domestic Violence Jurisdiction Over Non-Indian Defendants, 127 HARV. L. REV. 1509, 1518 (2014) (stating that the Court replaced Congress as the federal agent responsible for Indian affairs by "finding tribal divesture of sovereignty in congressional silence").

185. 478 U.S. $221,229-30(1986)$.

186. Id. at 230 (quoting United States v. Cannon, 642 F.2d 1373, 1379 (D.C. Cir. 1981)).

187. Id.

188. Schneider v. Kissinger, 412 F.3d 190, 197 (D.C. Cir. 2005). 
measures should be taken in matters of foreign policy and national security is not the stuff of adjudication, but of policymaking." ${ }^{89}$

In the case of the implicit divestiture doctrine, courts do not even wait for the political branches to affirmatively act to state a policy, but instead undertake to make the policy in the absence of political direction. As a result, a single case or controversy is not limited to the facts or capacities of a particular tribe. Instead, a decision, like Oliphant or Duro, can announce a rule that in an instant may deprive all 567 federally recognized tribes of inherent jurisdiction without regard for individualized, local, tribal, or national consequences, under circumstances in which the vast majority of tribes are not parties or participants. Such a deprivation - or affirmation - of tribal authority calls for a more nuanced determination than judicial deliberations are able to provide. ${ }^{190}$

The Court's implicit divestiture test, in which it decides whether the United States will recognize tribal assertions of inherent authority, is analogous in many ways to the question of whether a tribe has been federally recognized. Congress has predicated most of the federal programs and services available to Indian tribes and Indian people upon the existence of federal recognition, or acknowledgement, of the Indian tribe as a political entity. The relationship between federally recognized Indian tribes and the federal government results in unique benefits and responsibilities pursuant to the federal-tribal trust relationship. Traditionally, the power to recognize foreign nations or governments rests with the executive branch; in the context of Indian affairs, the power to recognize an Indian tribe for purposes of a government-to-government relationship lies with both political branches. ${ }^{191}$ Whether a tribe has been federally recognized is generally thought to be one of the quintessential political questions and "lies at the heart of the doctrine of "political questions."'192 Indeed, the judiciary has generally shown

189. Id

190. Id. ("As the Supreme Court has emphasized, 'the "nuances" of "the foreign policy of the United States ... are much more the province of the Executive Branch and Congress than of this Court."' (quoting Crosby v. Nat'l Foreign Trade Council, 530 U.S. 363, 386 (2000))); see also Steele, supra note 18.

191. See Miami Nation of Indians of Ind., Inc. v. U.S. Dep't of the Interior, 255 F.3d 342, 346-48 (7th Cir. 2001). Federal recognition, or acknowledgement, affirming a tribe's government-togovernment relationship with the federal government is accomplished either through congressional approval or through the administrative acknowledgement process. Kirsten Matoy Carlson, Congress, Tribal Recognition, and Legislative-Administrative Multiplicity, 91 IND. L.J. (forthcoming 2016), SSRN: http://ssm.com/abstract=2619288 orhttp://dx.doi.org/10.2139/ssm.2619288 (empirically demonstrating that Congress plays a significant role in federal tribal recognition and demonstrating that "[s]ince the 1970 s... OFA and Congress have emerged as the two institutions most likely to extend federal recognition to Indian tribes.").

192. The Seventh Circuit considered, in Miami Nation, whether the Department of Interior's decisions and regulations implementing the power delegated from Congress to regulate federal tribal 
great deference on the subject of federal tribal recognition, holding that the status of Indians - as dependents or as citizens - is "a political question, which the courts may not determine," as that status is a policy question for the legislative branch. ${ }^{193}$

The implicit divestiture inquiry is also reminiscent of the kinds of political questions that courts have avoided in the context of federal tribal recognition. Courts have left to the policymakers to determine-informed by any number of factors, including unique histories, treaties, and other agreements - whether to extend federal recognition, because this question is not within judicial competence. ${ }^{194}$ But these questions about federal recognition are strikingly similar to the kinds of questions federal courts now routinely engage under the implicit divestiture inquiry - looking to history and vague notions of external-internal relations, for example, or compatibility with dependent-status tests. Congress is much better positioned to weigh the particular considerations governing which powers of tribal sovereignty the federal government will or will not recognize and affirm because the weighing involves political considerations rather than judicial questions. ${ }^{195}$

recognition are judicially reviewable. Miami Nation, 255 F.3d at 347 . The political question doctrine, the court wrote, "identifies a class of questions that . . . are not amenable to judicial resolution because the relevant considerations are beyond the courts' capacity to gather and weigh." Id. (citing Nixon v. United States, 506 U.S. 224, 228-29 (1993)). The inquiry under this branch of the political question doctrine "focuses on the nature of the questions" that courts must answer and "whether the answers would be ones a federal court could give without ceasing to be a court, ones within the cognitive competence, as distinct from the authority, of federal judges." Id. Looking to Luther v. Borden, 48 U.S. (7 How.) 1 (1849), the court determined that political questions are those where the "methods of litigation" make gathering the relevant facts and formulating a guiding "legal concept" for decision very difficult. Id. In Miami Nation, the Seventh Circuit found that indeed the court could take sufficient cognizance as to whether the federal acknowledgement regulations promulgated by the Department of the Interior meet Administrative Procedure Act (APA) standards. As a result, the specific question of the reviewability of the Secretary's decision in Miami Nation was answered in the affirmative: It was reviewable for compliance with the APA. Id. at 348 . To be sure, the court acknowledged that whether a tribe had been federally recognized would probably be an unreviewable political question were it not for the promulgation of "law-like" regulations by the Secretary that took the question presented out of the unfettered policy discretion of the Executive and transformed it into a reviewable, legal question of whether the Secretary had complied with the APA in the application of the regulation. Id. at 349.

193. United States v. Rickert, 188 U.S. 432, 445 (1903); see also United States v. Sandoval, 231 U.S. 28, 46 (1913) ("[I]n respect of distinctly Indian communities the questions whether, to what extent, and for what time they shall be recognized and dealt with as dependent tribes requiring this guardianship and protection of the United States are to be determined by Congress, and not by the courts.").

194. See, e.g., United States v. Sandoval, 231 U.S. 28, 46-47 (1913) ("[I]n respect of distinctly Indian communities the questions whether, to what extent, and for what time they shall be recognized and dealt with as dependent tribes ... are to be determined by Congress, and not by the courts.").

195. See Steele, supra note 18, at 783-814. 


\section{B. The Effects and Limits of the Political Question Doctrine}

There are several significant impediments and objections to adopting the approach outlined in this Article. First, the courts are unlikely to upend nearly forty years of precedent presuming the justiciability of cases addressing inherent jurisdiction and employing implicit divestiture; institutions generally do not relinquish their own power, and the principle of stare decisis suggests that the justiciability of implicit divestiture questions is settled law under Oliphant and its progeny. Still, the Court can justifiably reverse course after examining the struggle of lower courts to find judicially manageable standards. ${ }^{196}$ As the Court did in Garcia v. San Antonio Metropolitan Transit Authority, it can undo precedent when presented with evidence of the infirmity of its previously announced standards. ${ }^{197}$

Second, application of the political question doctrine to determinations of inherent tribal authority leaves tribes seeking to exercise inherent authority, as well as litigants seeking to challenge that authority, vulnerable to the political process. Leaving the interests of an insular minority to the whim of the political process generally runs counter to our sense of justice and propriety under a system of checks and balances that has built-in protections for minority interests against the tyranny of the majority. Should Congress act to strip tribes of authority tribes deem essential to tribal self-governance, they would have no recourse to the judiciary under this proposal. Yet, similarly, should Congress act to recognize and affirm tribal authority, those who oppose that authority would not have a judicial recourse either-short of an individual rights constitutional claim - and would need instead to work through the political branches.

This objection has substantial sway, as the intransigence of the political branches on issues large and small can hardly be overstated. When even powerful majority interests often cannot successfully navigate the political process to get sufficient congressional action or attention, mustering adequate political capital for minority interests is even more challenging. Although Congress has acted in recent years both to regulate and empower tribes through laws such as the Tribal Law and Order Act, ${ }^{198}$ the Indian Health Care Improvement Act, ${ }^{199}$ and the trib-

196. See Garcia v. San Antonio Metro. Transit Auth., 469 U.S. 528, 557 (1985) (Powell, J., dissenting).

197. Id. ("Attempts by other courts since then to draw guidance from this model have proved it both impracticable and doctrinally barren."); see Steele, supra note 18, at 791 ("In National League of Cities, the Court attempted to define a core of essential state sovereignty in order to protect the state-sovereigns from undue intrusion by Congress. Significantly, less than ten years later, the Court abandoned the task after finding itself unable to develop meaningful, judicially-manageable standards for applying its own tests." (footnote omitted)).

198. Tribal Law and Order Act, Pub. L. No. 111-211, 124 Stat. 2258 (2010). 
al domestic violence provisions of the Violence Against Women Act Reauthorization, ${ }^{200}$ there are many issues critical to tribes that continue to be unaddressed by Congress.

Political vulnerability can also mean instability. Tribes have not been able to anticipate the arc of inherent tribal authority policy emanating from the Court on this issue, and that lack of stability has been detrimental to the exercise of tribal jurisdiction. But taking courts out of the equation may not provide for greater stability and predictability. Political winds may blow in favor of tribal interests for a certain period, and then the winds may shift against tribal interests. With no recourse to the judiciary, these shifting political winds may mean continued upheaval for the foundations of tribal jurisdiction.

Still, given the Court's broad view of the plenary power doctrine, it is not at all clear that tribes lose anything meaningful, either in substance or process, in losing justiciability of questions of inherent tribal authority. The Court has yet to find that Congress has meaningfully exceeded its plenary power in acting to regulate tribes. If anything, the judicial review currently available to tribes in this realm is a remedy in theory more than in fact. And if tribes or other litigants believe Congress has violated a constitutional restraint on the plenary power, those claims are still subject to review. ${ }^{201}$

It is also clear that application of the political question doctrine in Indian affairs would face significant, continued opposition from tribes and scholars. The sting of Lone Wolf has not abated. For many, the political question doctrine stands for the proposition that the United States has a free hand to abandon treaty promises and is therefore not only suspect, but repugnant. Walter EchoHawk devotes a chapter to the legacy of Lone Wolf in his study, In the Courts of the Conqueror: The 10 Worst Indian Law Cases Ever Decided. ${ }^{202}$ Echo-Hawk observes that the "dubious" principle underlying the plenary power and political question doctrines in Indian law is the presumed inferiority of the Native people. ${ }^{203}$ As a result, " $[\mathrm{t}]$ he Court declared that Congress's plenary political power over Indians is absolute - that is, beyond the rule of law-because it is not subject to judicial review, and it includes the raw power to abrogate treaties." 204 Echo-Hawk is more than skeptical of the Court's abandonment of the tribes to the political pro-

\footnotetext{
199. Indian Health Care Improvement Act, Part III, sec. 10221 of the Patient Protection and Affordable Healthcare Act, Pub. L. No. 111-148, 124 Stat. 935 (2010).

200. Violence Against Women Reauthorization Act of 2013, Pub. L. No. 113-4, Tit. IX, 127 Stat. 54, 118-26 (2013).

201. See, e.g., Del. Tribal Bus. Comm. v. Weeks, 430 U.S. 73, 84 (1977).

202. ECHO-HAWK, supra note 46.

203. Id. at 163.

204. Id.
} 
cess given the Court's assertion that the plenary nature of political power over Indians is virtually unchecked: "The sole check on that unlimited power was a bare presumption that Congress will exercise it in 'perfect good faith."'205 Many tribes are therefore unlikely to now embrace or endorse a renewed political question doctrine without some concomitant plenary power reform. The counterargument, again, may be a frank assessment of what check, if any, the judiciary has provided - or may yet provide in the future - given the courts' pattern of undervaluing tribal sovereignty.

Scholars and courts also seem to be growing more skeptical of the political question doctrine generally and have raised a number of critiques that suggest it is a doctrine on the decline. ${ }^{206}$ They view the right to judicial review, a right that has gained rather than lost saliency, as being undermined by any expansion of the political question doctrine. ${ }^{207}$ Many may legitimately object to institutionalizing a lesser right of judicial review for a certain class of Americans: Indian tribes. To be sure, this Article does not argue for a wholesale embrace of the political question doctrine in Indian affairs. Instead, the Article seeks to engage in a discussion of whether the doctrine may have some application to the implicit divestiture inquiry. Given the treatment of the implicit divestiture doctrine by the courts thus far, whether tribes have access to meaningful judicial review under current precedent is subject to debate.

It also may be that the same end-removing the courts from setting unprincipled federal Indian policy under the inherent tribal sovereignty question-could

205. Id. (quoting Lone Wolf v. Hitchcock, 187 U.S. 553, 566 (1903)).

206. See, e.g., Rachel E. Barkow, More Supreme Than Court? The Fall of the Political Question Doctrine and the Rise of Judicial Supremacy, 102 COLUM. L. REV. 237, 267 (2002); Linda Sandstrom Simard, Standing Alone: Do We Still Need the Political Question Doctrine? 100 DICK. L. REV. 303, 304-06 (1996) (observing - in 1999 - that "[s]ince Baker, the Court has dismissed only two cases on the ground that they involved a nonjusticiable political question, while expressly rejecting the application of the doctrine in more than a dozen cases").

207. Legal luminaries such as Erwin Chemerinsky and Martin H. Redish have both mounted vehement critiques of the political question doctrine. See Barkow, supra note 206, at $244 \mathrm{n} .19$ (positing that judicial review circumvents "the most fundamental purpose of the Constitution: safeguarding matters from majority rule" (quoting ERWIN CHEMERINSKY, INTERPRETING THE CONSTITUTION 99-100 (1987) and arguing that the "moral cost" of "the judicial abdication of the review function" outweigh any perceived benefits (quoting Martin H. Redish, Judicial Review and the 'Political Question', 79 NW. U. L. REV. 1031, 1060 (1985))). However, this trend away from the political question doctrine generally may not be consistent with more recent cases in the realm of foreign affairs, where a doctrine of "deference" seems to have taken on new life. See, e.g., Developments in the Law, Access to Courts, 122 HARV. L. REV. 1151, 1194-96, 1196 n.17 (2009) (discussing a trend in foreign relations law of greater judicial deference, even if not specific invocation of the political question doctrine and stating that "[w]hen the political questions doctrine fell into desuetude after Baker v. Carr, it was replaced as an avoidance device by the standing doctrine" (citing HOWARD P. FINK \& MARK V. TUSHNET, FEDERAL JURISDICTION 231 (2d ed. 1987))). 
be achieved through other means. Courts could develop some meaningful limits on the plenary power doctrine that would enhance rather than retract tribal access to judicial review. Congress could also legislate guiding policy principles that would clarify the boundaries of inherent tribal sovereignty. Congress has demonstrated that it can act in this realm, for instance enacting the so-called "Duro fix" and affirming inherent tribal authority over all persons in the domestic violence context. ${ }^{208}$ Since Congress is uniquely positioned to craft policies that draw upon and balance the variety of public interests, and these policies can be tailored to the variety of tribal interests and capacities, Congress could take this question away from the courts. Congress has the authority to assert its primacy in this realm, and it is possible, if not likely, that the Court would defer to the policy judgments of Congress. ${ }^{209}$ Congress, however, has for the most part tolerated the intrusion by the courts into the realm of federal Indian policy.

Without discounting these significant concerns, this Article seeks to foster a greater debate about the proper role of courts and of Congress in determining the contours of inherent tribal authority. Federal Indian law is replete with examples of salvaging useful principles out of adverse precedent. Perhaps the political question doctrine may have some future role to play in clarifying the doctrine of inherent tribal authority and in limiting the damage inflicted by the implicit divestiture doctrine.

\section{CONCLUSION}

Courts have suggested on the one hand that questions about whether Congress can unilaterally abrogate a treaty, or whether a particular tribe is federally recognized, are political questions. At the same time, courts have found the inquiry into which powers may have been implicitly divested from tribes to be justiciable. The Supreme Court's doctrine of implicit divestiture invades the purview of Congress and erodes inherent tribal authority without the input of Congress. It violates the ideal of coexisting sovereigns, each steering its own canoe, neither endeavoring to steer the other. The implicit divestiture inquiry has evolved to exhibit the defining characteristics of political questions: The standards applied are not intelligible, judicially manageable, or predictable.

The judicial inquiry into retained inherent tribal powers has failed to produce core, consistent principles from which a court could reason in defining a tribe's retained sovereignty. Thus, courts should presume that tribes have re-

208. 25 U.S.C. $\$ \$ 1301-03(2012)$.

209. See United States v. Lara, 541 U.S. 193, 199-200 (2004). 
tained inherent authority unless Congress has specifically and explicitly divested the tribe of that particular authority. In the face of express congressional recognition of tribal inherent authority or congressional silence on the matter, challenges by individuals who object to a tribe's exercise of authority should be declared nonjusticiable, political questions. Conversely, tribal challenges to congressional diminutions of inherent tribal authority must likewise be treated as political questions. This more consistent approach ultimately leaves the scope of inherent tribal authority in the hands of Congress alone, a result that guarantees that these critical policy decisions, which are fundamentally political, are made by the politically-accountable Congress. 